•综述・

\title{
生物入侵对黄河流域生态系统的影响及对策
}

\author{
殷万东“* 吴明可\#田宝良 于宏伟 王麒云 丁建清
}

(河南大学生命科学学院作物逆境适应与改良国家重点实验室, 河南开封 475004)

\begin{abstract}
摘要：黄河流域健康的生态系统是沿黄地区生态保护和高质量发展的核心。然而, 随着经济高速发展和人类活动 增加, 大量的外来生物传入并占据黄河流域生态位。这些外来生物在黄河流域的大死扩繁给黄河流域本土生物和 生态系统带来了严重威胁, 甚至严重影响人类健康。因此, 研究黄河流域的外来生物入侵问题, 并提出保护对策, 对于黄河流域生态保护和高质量发展具有重大意义。本文主要从黄河流经九省区(包含黄河流域)外来入侵生物的 传入特征、传播途径、种群动态、成灾机制以及入侵生物对黄河流域重要生物资源和生态系统的影响等方面进行 综述，并提出了防控黄河流域生物入侵、保护黄河流域健康的生态系统的措施和对策。
\end{abstract}

关键词: 黄河流域; 黄河九省区; 生物入侵; 生态系统; 生物多样性

\section{Effects of bio-invasion on the Yellow River basin ecosystem and its countermeasures}

Wandong Yin ${ }^{\# *}$, Mingke Wu* ${ }^{\#}$ Baoliang Tian, Hongwei Yu, Qiyun Wang, Jianqing Ding

State Key Laboratory of Crop Stress Adaptation and Improvement, School of Life Sciences, Henan University, Kaifeng, Henan 475004

Abstract: A healthy ecosystem in the Yellow River basin is central to ecological protection and high-quality development along the Yellow River region. However, the rapid development in the economy and increase in human activity has resulted in a large number of invasive species being introduced into the Yellow River basin and occupying native species ecological niches. The outbreak and spread of invasive species pose a serious threat to native organisms and ecosystems in the Yellow River basin and can even seriously affect human health. Therefore, it is important for the ecological protection and high-quality development of the Yellow River basin to study the invasion of alien species in the Yellow River basin and to put forward strategies for the protection of native species. Here, we review the bio-invasion characteristics, transmission approaches and mechanisms in the nine provinces of Yellow River basin, and the effects of bio-invasion on the biological resources and ecological system in the Yellow River basin. We then suggest measures and countermeasures to reduce current effects of bio-invasion, protect the Yellow River healthy ecosystems, and ensure high-quality development.

Key words: Yellow River basin; nine provinces and regions along the Yellow River; biological invasion; ecosystem; biological diversity

黄河是我国第二大河，也是孕育中华文明的母 亲河。黄河流域西起青藏高原, 东至渤海, 南自秦 岭，北抵阴山，流经青海、四川、甘肃、宁夏、内 蒙古、山西、陕西、河南、山东等九省区, 干流全 长约 $5,400 \mathrm{~km}$, 总流域面积超 75 万 $\mathrm{km}^{2}$, 流域内总人
口约 4.2 亿，占全国人口的近 $1 / 3$ (李开明等, 2013)。 黄河流域既是我国的矿产资源富集区，也是农产品 主产区，更是一道重要的生态屏障，在我国的农业 发展、经济繁荣和生态安全等方面均具有重要的战 略地位(陈耀等, 2020)。然而, 由于自然和人为等多

收稿日期: 2020-05-20; 接受日期: 2020-11-02

基金项目: 河南省重大公益专项一一黄河中下游滩涂生态保护关键技术体系研究(201300311300)和河南省高等学校重点科研项目(20A180008)

\# 共同第一作者 Co-first authors

* 通讯作者 Author for correspondence. E-mail: wojiaowandong1@163.com 
种因素的影响，黄河流域生态环境变得极其脆弱。 因此, 如何维持黄河流域生态系统的健康和稳定成 为当前沿黄地区高质量发展和生态保护的核心。

生物入侵作为全球性环境问题, 严重影响着入 侵地的生态安全、经济发展及人类健康(万方浩等, 2002; Ding et al, 2008)。外来物种的入侵会改变原有 生物的地理分布和自然生态系统的结构与功能, 导 致生态灾害暴发及生物多样性的丧失, 进而威胁到 人类生存环境, 以及农林牧副渔业的发展(鞠瑞亭 等, 2012; 吴吴和丁建清, 2014)。近几十年来, 随着 经济的高速发展和人类活动的加剧, 大量的外来生 物已经传入并占据了黄河流域生态位, 对黄河流域 本土生物及生态系统造成了严重威胁(赵怀浩等, 2011)。例如, 三叶鬼针草(Bidens pilosa)作为黄河流 域常见的入侵杂草, 由于其较强的化感作用和快速 生长繁殖特性，常抑制周围植株生长并侵占自然资 源, 对黄河流域的生态环境和生物多样性造成巨大 威胁(李振宇和解炎, 2002; 苑晓雯, 2011 ${ }^{\circledR}$; 邓玲姣 和邹知明, 2012)。而从流域角度综合探究入侵生物 对流域及周边生物多样性和生态安全的影响, 不仅 有利于维持黄河流域生态系统的结构稳定性, 还将 为制定黄河流域生物多样性的保护对策, 减少外来 有害生物对当地的危害提供理论依据(邱建生等, 2019)。因此, 研究黄河流域的外来生物入侵问题, 并提出保护对策，对于黄河流域生态保护和高质量 发展具有重大意义。

目前, 已有研究报道了生物入侵对珠江和长江 等流域的水生和陆生生物多样性、生态环境和水资 源的影响(陈家长等, 2010; 冯洪超等, 2015; 高宇等, 2017)。然而黄河流域因其自身的特异性, 如干流 长、地势多变、地形复杂，且流域内人口众多，发 展模式以农业生产为主(陈耀等, 2020; 张红武, 2020)，急需开展生物入侵对于黄河流域(农业)生态 系统和生物多样性影响的研究。虽然我国对于生物 入侵的认知和防治技术已显著提高, 关于黄河流域 生物入侵的研究也逐渐增多(刘庆年等, 2006; 李芳 等, 2008), 但是生物入侵对黄河流域生态环境和生 物多样性的影响仍然缺乏系统性研究和论述。因此, 本文在文献调研黄河流域所在九省区外来物种发 生现状的基础上，综述黄河流域九省区入侵物种的

(1) 苑晓雯 (2011) 黄河流域河南段菊科主要外来种对不同环境梯度的 适应性研究. 硕士学位论文, 河南大学, 开封.
发生特点、入侵途径、成灾机制，以及生物入侵对 于黄河流域生态系统的影响，并提出相应的防治对 策。这对于黄河流域生态保护和有害生物治理具有 很好的借鉴意义。

\section{1 黄河流域所在九省区外来入侵物种的 特点}

黄河流域地貌特征复杂、气候环境多样(严昌荣 等，2006), 可以为不同种类的动植物提供合适的栖 息场所。鉴于黄河流域生物入侵的报道相对较少, 而外来物种在黄河流域所在九省区的入侵势必会 对黄河流域生态安全造成潜在威胁, 我们对黄河所 在九省区(包含黄河流域)的生物入侵文献和书籍进 行调研和整理。结果发现：黄河流经九省区外来入 侵植物达194种(附录1), 隶属于49科128属。其中种 类最多的为菊科, 含 24 属 35 种; 豆科次之, 含 15 属 26种 (图 1)。根据植物生活型统计，草本植物占 $73.19 \%$, 包括一年生草本植物 80 种，多年生草本植 物77种, 其他植物(藤本植物、肉质植物、灌木和乔 木)占 $26.81 \%$ 。外来入侵动物(昆虫纲、鱼纲、两栖 纲、爬行纲等)达 90 种，隶属于 22 目53科，其中昆虫 纲最多 (7目 52 种), 约占入侵动物物种数的 $58 \%$; 其 次是鱼纲, 共计 30 种, 而鲈形目种数占鱼纲总数的 1/4 (图1)。由此可见，黄河流经九省区的外来动植 物种类繁多，分布区域广泛，潜在暴发危害的风险 性较大。

IUCN公布的最危险的 100 种入侵物种中，有 16 种在黄河流经九省区建立了自然种群(附录2), 包括 入侵河流、池塘、湖泊等水生生境的风眼莲 (Eichhornia crassipes)、入侵农田生态系统的重要害 虫烟粉虫(Bemisia tabaci)、入侵黄河自然水域的鱼 类虹鳟(Oncorhynchus mykiss)、入侵草地等生境的红 火蚁(Solenopsis invicta)、入侵黄河滩涂湿地的大米 草(Spartina anglica)等。而生态环境部公布的71种有 重大危害的外来入侵物种名单中，已有 40 种入侵到 黄河流经九省区(附录3), 包括有“植物杀手”之称的 黄顶菊(Flaveria bidentis), 该物种目前已经扩散至 黄河中下游地区的河南、山东、山西境内(郑志金等, 2018)；自然湿地的 “超级入侵植物”互花米草 (Spartina alterniflora) 和大米草，目前已经广泛分布 于黄河三角洲绝大多数滩涂地(解雪峰等, 2020); 滩涂地的“软体杀手”泥螺 (Bullacta exarata), 
目前已经遍布黄河下游滩涂地潮间带(刘童等, 2018)。这些危害性极大的入侵物种在黄河流经九省 区的暴发危害及蔓延, 会为黄河流域生态系统的健 康发展带来极大的安全隐患。

在黄河九省区, 外来物种侵入的生态系统复杂 多样，目前遍布于农田、果园、牧场、城市、路域、 草地、林地、湿地、淡水等陆地和水域生态系统(图 2)。其中，入侵路域生态系统的外来物种数最多, 达 103种，这表明发达的交通运输网会促进物种的入 侵和扩散; 其次为农田生态系统(其中入侵动物30 种, 植物59种)。而黄河流域, 尤其是中下游地区, 作为中原粮仓, 外来物种对其农田生态系统的侵入 暴发势必会对粮食生产造成不利影响。值得注意的 是, 淡水生态系统(河流、湖泊、池塘等)中的入侵动 植物已高达64种，这对于黄河流域的淡水供应有极 大的安全隐患。此外, 我们发现这些外来物种来源

(A)

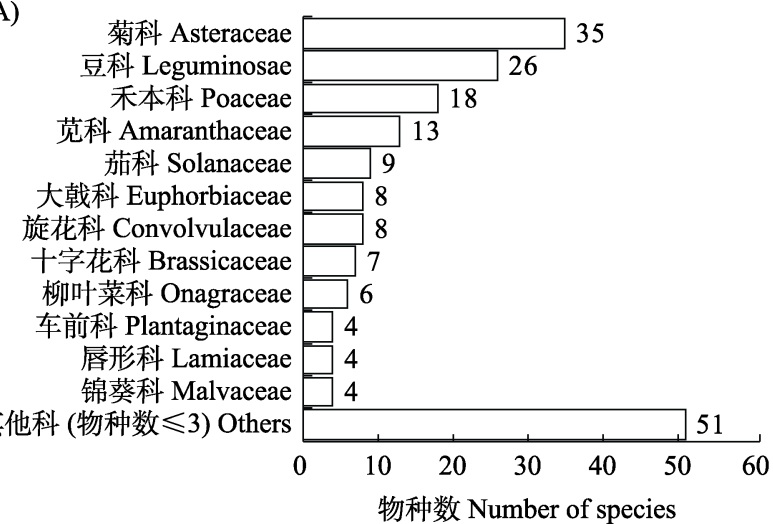

于全球各大洲(南极洲除外), 其中起源于北美洲的 最多，有 113 种，占总物种数的 $39.65 \%$; 而原产地为 非洲和大洋洲的最少，分别占 $13.33 \%$ 和 $2.46 \%$ 。

黄河流域所在各省区均有几十种甚至上百种 入侵生物发生, 且入侵物种丰富度呈现出由西往东 递增的趋势(图3)。黄河下游的山东省由于地势特殊, 且黄河三角洲形成的独特湿地生态系统为外来生 物提供了良好的栖息环境, 因此入侵物种丰富度最 高，约占黄河九省区入侵物种总数的 $15 \%$ 。而位于 黄河上游的宁夏和青海的入侵种较少，各占 $8 \%$ 左 右。这可能与气候差异以及人口、交通、贸易密集 程度有关。尤其是宁夏和青海两个地区的平均海拔 较高, 盆地所占范围广, 且多处于荒漠地带, 地形 地貌复杂，因此大多数外来生物很难在该地区进行 建群和扩散。而黄河中下游地区属于半湿润的气候 环境, 人口较多, 交通运输发达, 贸易往来频繁,

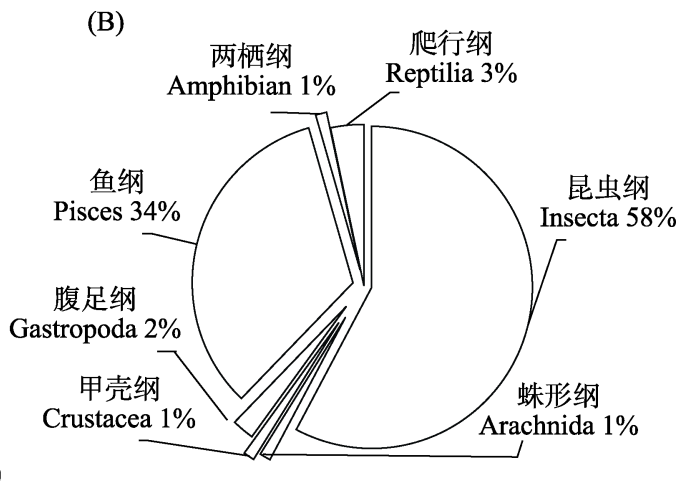

图1 黄河流经九省区外来入侵植物(左)和动物(右)分类图

Fig. 1 Classification charts of alien invasive plants (left) and animals (right) in nine provinces along the Yellow River

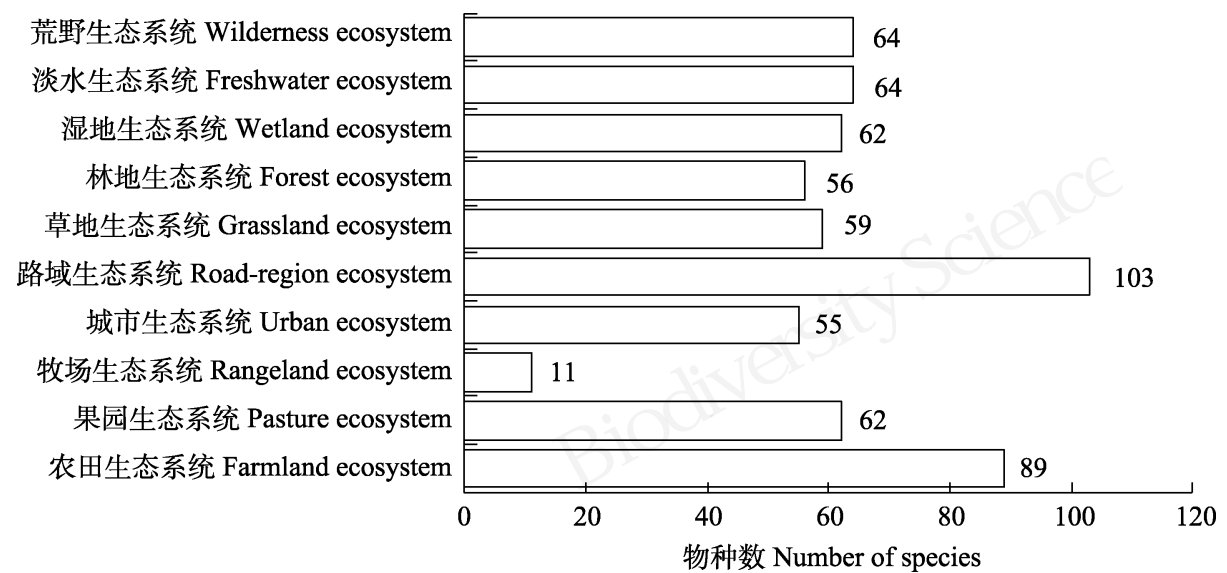

图2 黄河流经九省区外来生物入侵在不同生态系统的数量分布

Fig. 2 The number of invasive species in different ecosystems in nine provinces along the Yellow River 


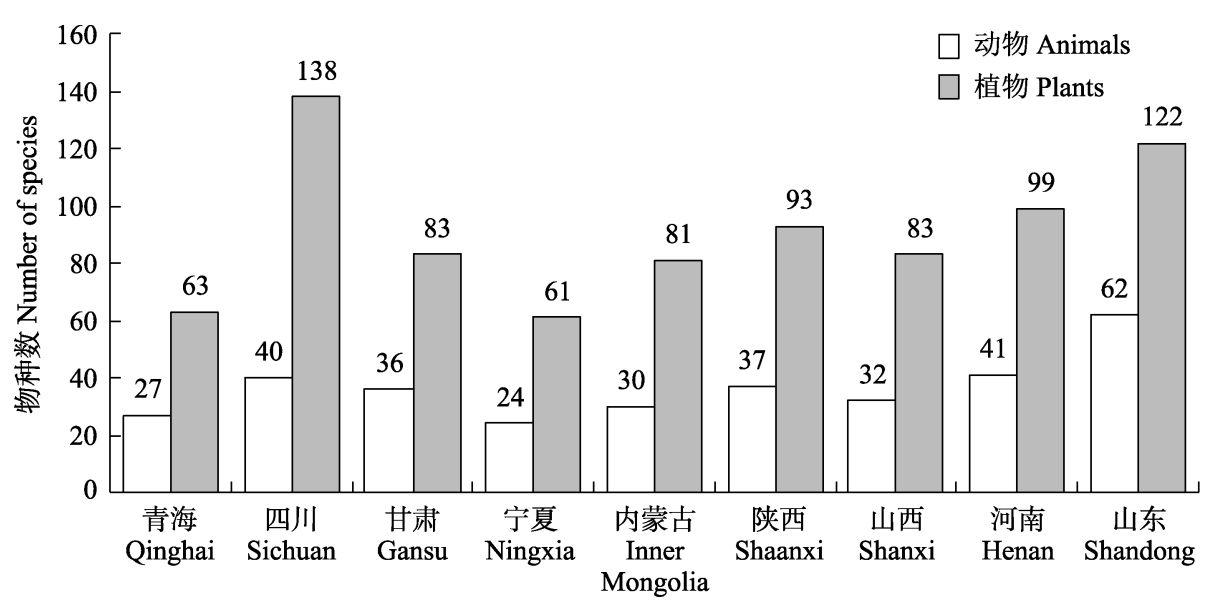

图3 黄河流经九省区外来入侵生物丰富度分布图

Fig. 3 Distribution chart of alien invasive species richness in nine provinces along the Yellow River

这些条件均有利于外来物种的入侵和扩散。值得注 意的是, 由于黄河上游四川段在纬度上偏南, 温 度、光照等气候条件适宜, 地貌特征复杂, 因此四 川段外来物种丰富度也较高, 约占总数的 $14 \%$ 。

\section{2 外来物种入侵的主要途径及发展趋势}

同多数生物入侵途径相似，黄河流域的外来物 种主要通过人类活动有意或者无意引入。其中, 作 为有用物种引进、随着交通工具或者货物进入和自 然扩散是三种最主要的途径。而且, 我们发现许多 物种的引进扩散并非由单一途径导致(图4)。近些年, 黄河流域的运输业、旅游业及贸易往来的飞速发展 以及西部大开发的推进, 为物种入侵及扩散提供了 绝佳条件。

(1)高价值物种引进。由于在原产地表现出良好 的应用价值, 许多物种被有意引入黄河九省区的陆 生和水生生境。然而, 由于管理不善或者人为疏忽, 造成了物种的逃逸并在野外建立自然种群完成入 侵。我们发现, 黄河流经九省区的入侵物种中有 $61.4 \%$ (植物 136 种, 动物 37 种) 是通过人为引进有用 物种的方式侵入的(图4)。例如, 用于防风固堤和改 良土壤的互花米草, 被引入黄河三角洲后迅速扩张, 目前在黄河滩涂地成为优势物种(路峰和王昕, 2017; 汪方芳等, 2020); 作为饲料引种的风眼莲和空心莲 子草(Alternanthera philoxeroides)在黄河中下游地区 发生严重(吴軕等, 2007); 作为优良牧草引入到内 蒙古地区的紫花苜莄(Medicago sativa)、白花草木樨 (Melilotus albus)等极易排挤本地牧草, 破坏当地牧
区的生态平衡(张璞进等, 2019); 用于观赏的加拿 大一枝黄花(Solidago canadensis)、铜锤草(Oxalis corymbosa) 等, 在山东济南、河南郑州等地区的公 园引入种植, 现已逸生为野生杂草(吴䑣等, 2007; 李长看等, 2011); 当作宠物引入的鳄龟(Chelydra serpentine)目前已出现在黄河中游自然水域(张红星, 2010); 作为水产引种到黄河流域的泥螺、克氏原螯 虾(Procambarus clarkii)等, 由于养殖管理不善, 已 经扩散到自然生境并造成不同程度的危害(李成和 谢锋, 2004; 刘童等, 2018)。在黄河上游地区, 许多 有价值的鱼类如斑点叉尾鮰(Ietalurus punetaus)、麦 穗鱼(Pseudorasbora parva)等被人为引入并在自然 水域饲养，严重影响土著物种生存(蒋红等, 2007; 张登成和郑娇莉, 2019)。有用物种的引入对当地的

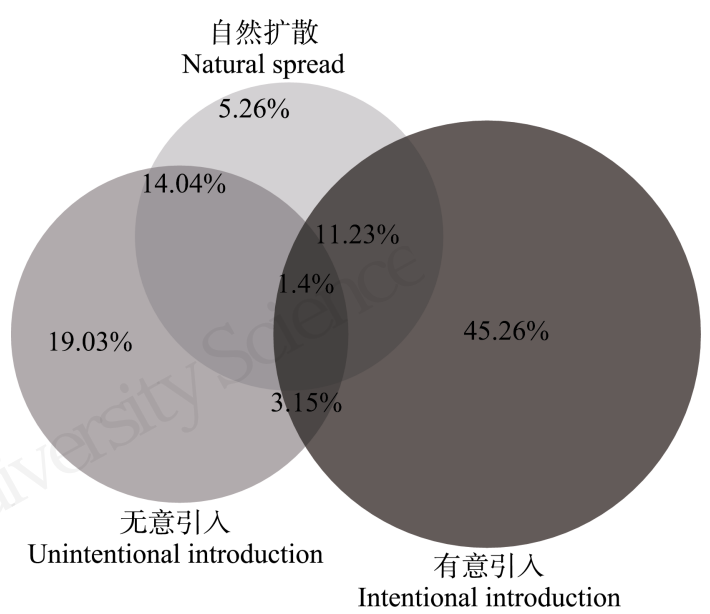

图4 黄河流经九省区入侵生物引入方式分布占比

Fig. 4 Ratio of introduction mode of alien invasive species in nine provinces along the Yellow River 
经济社会发展无疑有促进作用，但同时又为生物入 侵提供了条件。作为黄河流域外来物种入侵的最重 要途径, 如何引入和规范管理有价值的外来物种是 保护黄河流域生物多样性急需解决的重要问题。

(2)发达的交通工具和网络。交通工具和货物运 输是大多数物种入侵我国的主要途径(吴吴和丁建 清, 2014)。通过文献调研发现, 38.25\%的入侵物种通 过交通工具或者货物侵入黄河流域所在九省区。黄 河流域, 尤其是中下游地区, 地处中国南北过渡带, 交通发达，人口众多且流动性大，贸易往来频繁， 旅游业繁盛, 这对于物种入侵和扩散提供了便利条 件。而西部大开发的推进, 交通运输网的进一步完 善, 将会加大黄河上游地区物种入侵的速度。此外, 黄河流域滩涂地保护、退耕还林、水土流失控制、 防风固沙、水域污染治理等措施的进一步实施，均 需大面积引进和种植外来物种, 这会增加外来物种 入侵黄河流域的风险。随着黄河流域农业、经济及 社会一体化发展, 人类活动导致的外来物种入侵及 传播速度将会进一步加快。

(3)自然扩散传入。大多数外来种自身扩散能力 有限, 但是可以借助风力、水流等自然力传播。而 黄河九省区有 $31.57 \%$ 的外来物种通过自然扩散进 入。如近年在全球暴发危害的迁飞性害虫草地贪夜 蛾(Spodoptera frugiperda), 2016年首次在非洲暴发 危害, 然而借助气象条件, 短短 16 个月入侵了超过 21个国家和地区(Stokstad, 2017)。在中国, 2019年1 月首次发现草地贪夜蛾侵入云南省江城县, 但至 5 月就已经快速扩散到黄河流域的四川、河南等地(姜 玉英等, 2019)。

\section{3 外来种成灾机制}

\section{1 黄河变道和人类活动的影响}

大量研究表明, 丰富的生物多样性和复杂的生 态系统是抵御外来物种入侵的重要基础(White \& Shurin, 2007; Frankow-Lindberg et al, 2009)。诸多理 论如干扰假说(disturbance hypothesis)、空生态位假 说(empty niche hypothesis)、多样性阻抗假说(biotic resistance hypothesis)等均表明, 生物多样性较低的 生境更容易被外来生物成功入侵(徐承远等, 2001; 王明娜等, 2014)。而黄河变道和人类开垦活动使得 黄河流域陆生和水生生境严重破坏, 导致生态结构 极不稳定, 生物多样性丧失, 对外来生物的抵抗力
减弱，这使得外来物种在黄河流域可能极易建立种 群，并快速扩散。

据史料记载(阎海青, 2009), 黄河曾经历过8次 变道, 每次变道均对生态系统稳定性造成毁灭性打 击，这也为外来物种的入侵提供了机会。近200年内, 黄河发生过两次大的变道。1855年，黄河在河南铜 瓦厢改道, 使得黄水北徙。河患下移至黄河下游, 且发生频率增多, 对黄河下游生态系统稳定性和生 物多样性造成更严重的危害(韩广轩等, 2011)。据统 计，自1855年黄河改道至清末的57年间，黄河下游 每年均有大小不等的黄河决溢事件发生，致使大面 积的草木、庄稼、动物等被淹没。洪水及其所携带 的大量泥沙，破坏了三角洲地区的自然地貌，毁坏 植被, 淤塞河道, 造成水系紊乱。此外，由于洪水灾 害，形成大面积的盐碱地，危害农林作物的生长(杨 立建等，2020)。1938年郑州花园口黄河决堤，致使 洪水泛滥于豫、苏、皖3省44县市，几十亿吨的泥沙 顺着决口涌入平原, 淤塞河道, 淹没田野, 改变地 质，形成危害严重的黄泛区。每年汛期，洪水都会 泛滥回流倒灌, 淹没农田和植被。洪水过后常引起 蝗灾, 蝗虫取食进一步毁坏农林作物和地表植被, 对当地农林牧副渔业及生态环境稳定性造成严重 破坏(钮本良, 1996; 喻宗仁等, 2004)。黄河变道导 致的原有生物多样性降低、生境破坏和空白生态位 的出现等均为外来物种的侵入定殖提供了条件。

人类活动的过度干扰导致黄河流域环境不断 恶化, 生物多样性丧失, 从而使生态系统结构与稳 定性进一步降低, 使得黄河流域极易被外来生物侵 入并暴发危害。黄河的主要特点是“水少沙多、水 沙异源、时空分布不均匀” (王颖和张永战, 1998)。 因此，流域周边的耕作理念多以“广种薄收、围湖造 田”为主，这导致黄河流域耕作无序、毁林开荒现象 严重, 致使黄河流域植被破坏和水土流失逐年加剧, 生态环境不断恶化(张小云, 2015; 王威和夏如兵, 2019)。据考古和历史记载，黄河中游曾经草木茂盛， 生物种类繁多，但是由于土地肥沃，气候适宜，交 通及灌溉引水便利, 黄河中下游滩涂地一直是我国 重要的粮棉和畜牧产品生产基地(郑利民, 2007; 吴 泽宁等, 2019)。然而, 过度开发利用以及黄河水患 常年发生导致下游滩区生态环境恶化，同时大量垦 殖、发展农牧业导致了流域中生物多样性锐减，如: 随着围湖造田面积日益增加, 湿地面积日益减少, 
使得三角洲大量植物或水生动物消失, 尤其是近岸 流域的浮游生物、底栖生物及洄游性生物减少和死 亡的现象频发, 而黄河口的大多水域已丧失保护鱼 类产卵功能，甚至发生赤潮灾害(高玉玲等, 2004; 李红娟等, 2009)。此外, 在农业生产过程中, 人们为 了提高土壤质量, 保证作物生长, 往往会向土壤中 大量输入化学肥料, 而这些肥料恰好成为入侵植物 的温床, 例如, 氮磷添加对黄河三角洲入侵植物互 花米草的研究证明, 土壤中氮磷含量的增加可显著 增强互花米草对本土芦苇(Phragmites communis)的 竞争能力 ${ }^{(1)}$ 。

\section{2 较强的适应进化能力的影响}

无论是动物还是植物, 入侵种通常具有较强的 环境适应能力, 尤其是在较差的生境仍可以成功存 活, 这使得外来种在与土著种竞争中具有空白资源 优势, 这也是内禀优势假说 (inherent superiority hypothesis)的核心观点。例如, 黄河中下游区域作为 中国重要的粮食主产区, 干旱缺水一直是粮食生产 的一大难题(曹永强等, 2014)。而入侵黄河中下游农 田系统的节节麦(Aegilops tauschii)对干旱有较强的 耐受性, 其可通过改变叶片形态和生理特性以快速 适应生境变化, 从而提高自身的竞争力(王宁等, 2019)。再如，入侵黄河流域四川段的马缆丹 (Lantana camara)生命力和适应性极强, 在极度缺 水和土壤贫痊生境仍能快速生长, 并且对不同生境 表现出高度的适应性, 在旷野、山沟底、山坡、草 地、路边等生境均能定殖扩繁(林英等, 2008; 张春 梅等, 2016)。此外, 黄河水环境的恶化会对多数水 生动物造成严重影响, 而入侵动物自身的较强适应 性反而成为其快速入侵繁殖的有利条件。比如：入 侵黄河上游地区的克氏原螯虾, 由于具有生境适应 性广、抗逆性强等特点, 所以当逃逸到水生动物较 少的污染水环境后, 能够迅速建立野生种群, 形成 单一优势群落, 进一步影响水生生物的多样性(蔡 凤金等, 2010)。

\section{3 天敌逃逸的影响}

自然界中，每种生物均有自身的天敌。生物与 其天敌长期的适应进化, 相互制约, 使其种群数量 能够保持动态平衡。然而, 外来种传入新的生境, 通常会缺失专食性天敌制约, 导致生物控制机制丧

(1) 王炳臣 (2014) 氮磷添加对黄河三角洲滨海湿地互花米草入侵影响. 硕士学位论文, 青岛科技大学, 山东青岛.
失，使得外来物种的种群数量短期内大幅增加，暴 发成灾(Keane \& Crawley，2002; Ren \& Zhang, 2009)。而且, 由于天敌的缺失, 外来生物可以把更 多的能量分配于自身生长繁殖、抗逆性增强和竞争 能力提高等方面，进而加速自身的扩散(Blossey \& Nötzold, 1995; Huang et al, 2010; Jack \& Friesen, 2019)。例如，在黄河流域河南段普遍发生的空心莲 子草, 由于逃离了其原产地专食性昆虫和病原微生 物的制约, 对于广食性昆虫和温度胁迫的抗性能力 显著强于本土同属植物，这导致未来气候变暖趋势 下，入侵植物竞争力还会进一步提高(潘晓云等, 2007; 刘珍, 2019 ${ }^{\circledR}$ )。

\section{4 生物入侵对黄河流域生态系统的危害}

\section{1 对生物多样性的影响}

外来生物在入侵地大量的繁殖和疯狂的扩张, 不但占据空生态位，而且会通过竞争挤占本土物种 的生态位, 导致本地种生活习性、生长繁殖、种群 动态发生改变, 甚至引起本地物种的灭绝, 进而引 发连锁性灭绝效应，降低生物多样性。例如，引种 到黄河三角洲进行养殖的泥螺, 在养殖过程中由于 出现逃逸现象，使得适应力极强的泥螺在自然生境 内迅速繁殖和扩散，短时间内成为黄河三角洲区域 滩涂地的优势种, 对本地传统贝类的生存产生极大 威胁(蒋万钊, 2014)。同时其体表能分泌一种毒素黏 液，导致其他贝类缺氧室息死亡，降低滩涂地生物 多样性，严重破坏黄河三角洲的生态平衡(赵文溪 等, 2017; Chen et al, 2020)。互花米草引入黄河三角 洲后快速扩繁，其密布区几乎已无其他本土植物存 活，而仅存互花米草单一群落(张俪文等, 2018; Xie et al, 2019)。此外，互花米草导致滩涂地栖息环境发 生变化, 使得土著物种如盐地碱蓬(Suaeda salsa)和 芦苇开始向陆地迁移 ${ }^{3}$ 。而这又会影响以本土植物 群落为食或作为栖息地的微生物种群、昆虫种群、 大型游泳动物和鸟类等的多样性和丰富度, 使得生 物多样性显著降低(侯栋梁等, 2015; Yang et al, 2018; 解雪峰等, 2020)。

(2) 刘珍 (2019) 增温对入侵植物空心莲子草与本土植食性昆虫互作关 系的影响. 硕士学位论文, 河南大学, 开封.

(3) 乔沛阳 (2019) 黄河三角洲入侵植物互花米草物理, 化学防治研究. 硕士学位论文, 内蒙古大学, 呼和浩特. 


\section{2 对群落生态系统的影响}

外来物种的暴发还会引起入侵地生境的极大 改变, 导致本土生物不再适宜生存, 造成环境恶化, 破坏生态系统的结构和功能, 严重影响群落生态系 统的稳定性。例如, 作为饲料引入中国的风眼莲, 目前广泛分布于黄河流域(潘怀剑和田家怡, 2001; 杜卫兵等, 2002; 黄文㰣等, 2019), 其以较强的繁殖 能力和逆境适应能力, 可以快速扩繁甚至覆盖整个 池塘、湖泊等水生生境, 从而形成致密的草垫(附录 4), 遮挡了光线, 并过度消耗水体内氧气和养分, 增强了水体的酸性, 改变了水体的理化性质, 从而 严重影响水体中的其他植物和动物的生存, 而动植 物的大量死亡又为病原体的滋生提供了适宜场所, 从而使得水质恶化, 水生生态系统彻底失衡(丁建 清, 2002; 李礼等, 2018)。

\section{3 对人类健康福祉和经济财产的影响}

多样化的生物群落和稳定的生态系统可以为 人类提供稳定的生态系统服务(ecosystem services), 这对于人类生存至关重要 (Díaz et al, 2019; Weiskopf et al, 2020)。然而, 外来种的侵入暴发会严 重影响生态系统的服务功能, 对人类的生命财产安 全造成不良影响。首先, 外来物种暴发会降低生态 系统的农产品供给服务, 直接造成重大的农林牧渔 业等的经济损失。如入侵农田生态系统的恶性杂草 节节麦和毒麦(Lolium temulentum), 因其竞争力极 强, 严重影响小麦等粮食作物的产量, 目前节节麦 在黄河流域的陕西、河南等小麦产区已有较多分布 (田朝阳等, 2005; 苏亚荵等, 2011)。迁飞型入侵害虫 (如草地贪夜蛾) 寄主范围极其广泛, 对农作物安全 造成极大的影响(杨普云等, 2019)。林木业生产上的 重大检疫害虫美国白蛾(Hyphantria cunea)和松材线 虫(Bursaphelenchus xylophilus)一旦暴发, 其危害对 于林业生产往往是毁灭性打击, 目前在黄河中下游 地区已有发生危害的报道(褚栋等, 2009)。而黄河流 域作为我国农产品的主产区, 尤其是黄河流经的中 下游地区是我国的主要粮仓, 生物入侵在农田生态 系统的暴发危害将会对我国的粮食生产以及社会 稳定造成严重影响。然而, 目前近90种外来生物已 经侵入黄河流域的农田生态系统中, 若不及时有效 控制, 将会给我国粮食生产带来巨大打击(间素丽 等, 2011; 郭屹立等, 2013; 陈怡平和傅伯杰, 2019;
耿明全, 2020)。外来物种暴发还会降低生态系统水 资源的供应，目前黄河流域水体污染严重，可利用 水资源十分紧张, 而外来生物的入侵大大降低了黄 河水资源的可利用性(章光新等, 2004; 张晓龙, 2005; 姜文来, 2010; 刘峰, 2015), 例如, 在黄河三 角洲, 反枝苋(Amaranthus retroflexus)作为外来入侵 植物, 种子在含水量较高的环境下能够迅速萌发, 其暴发危害需吸收大量土壤水分, 严重影响其他植 物的水资源供给(鲁萍等, 2010; 赵怀浩等, 2011)。相 似地, 牛筋草(Eleusine indica)在黄河流域广泛分布, 其根系发达, 有效截获土壤水分, 亦可造成土壤中 水资源的短缺 ${ }^{11}$ 。此外, 除了直接的经济损失, 国家 每年需要投入大量的人力和物力治理暴发危害的 入侵生物。例如, 全国范围内每年投入上百亿元治 理凤眼莲, 但凤眼莲极快的扩繁速度, 使得治理工 作收效甚微, 因此呈现出年年治理、年年泛滥的现 象(李博等, 2004)。

再者, 外来物种入侵还会影响生态系统的文化 服务功能, 如河道、湖泊等被凤眼莲入侵, 会导致 水质恶化, 臭气熏天, 影响人们的休闲生活。已入 侵黄河中下游地区的豚草(Ambrosia artemisiifolia) 会引起严重的过敏反应, 如哮喘和皮炎等, 是世界 性毒草(周忠实等, 2015)。在豚草开花季节, 过敏体 质的人不得不带上口罩或者远离豚草发生地, 严重 影响正常的生活(附录5)。

\section{黄河流域生物入侵防治对策}

\section{1 政府部门统筹安排, 加大基础理论研究}

政府统筹安排, 加强立法监督, 加大执法力度, 对于破坏生态系统行为予以严历处罚, 加强对黄河 流域原有生态系统和生物多样性的保护和修复, 提 高其自身抵抗和恢复水平。整合黄河流域各大高 校、科研单位相关资源, 加大生物入侵的基础研究 和人才培养, 并通过实地调查进一步探明黄河流域 生物入侵种类、数量和发生程度, 探究入侵机制, 建立模型预测适生区域及潜在生态危害等, 为有效 的防控措施提供理论基础。此外, 建立外来物种相 关信息数据库, 实现区域信息共享, 方便相关部门 和公众查看。同时, 利用先进的分子科学技术, 建

(1) 王新玲 (2016) 牛筋草与棉花的竞争作用及对草甘膦的抗药性研究. 硕士学位论文, 中国农业科学院, 北京. 
立黄河流域外来物种种质基因库和数据库, 加强基 因水平的研究，探究防控新途径。最终建立黄河流 域科学有效的生物入侵防控体系, 从而实现长治久 安的良好生态局面。

\section{2 严格规范引种制度, 完善引种后的监管}

目前, 人为引种是黄河流域外来物种入侵的重 要途径, 近半数的外来动植物入侵是有用物种引入 后逃逸造成的。然而, 经济发展和人们精神文化的 供给又离不开外来物种的引进。因此, 建立严格的 外来物种准入制度, 立法完善引种后的监管势在必 行。引种时应加强动植物检疫, 从源头上控制外来 物种的入侵。针对黄河流域现状, 建立统一的引种 综合评价中心, 从严要求引种前申报、专家评估及 审批; 强化引种过程中检疫部门的科学检疫, 避免 有害生物的带入; 重视引种后的监管, 建立引入物 种档案追踪制度, 并实现网络共享, 实行“谁引进 谁负责”机制，避免人为管理不善导致的自然逃逸 而造成的外来物种的入侵危害。此外，由于黄河流 域植树造林、滩涂地改造、环境绿化等需要引入大 量的苗木, 引种后可先通过区域示范, 明确外来种 在当地的生态扩繁表现, 在确定安全无害后, 再进 行大面积的应用和推广。

\section{3 提高监测预警水平，加强民众防范意识}

提高外来生物入侵的监测预警水平, 建立覆盖 全区域的动态监测网。针对外来种发生情况分级别 监测和防控, 如低等级别监控尚在人工饲养或种植 阶段的外来种; 中等级别预警和铲除已经逃逸并未 建立稳定自然种群的外来种; 重点部署和防控已经 局部暴发危害和具有暴发危害潜力的外来种。此外, 对于具有较强迁飞能力的外来物种如草地贪夜蛾、

东亚飞蝗(Locusta migratoria manilensis)等，因其一 旦侵入, 危害迅速且巨大, 应该建立专门的监测预 警中心，并制定相应的应急处理措施。由于黄河滩 涂地土质松软, 土壤理化性质适宜, 极为适合蝗虫 产卵繁殖, 这也是过去黄河流域蝗灾频发的重要原 因, 因此滩涂地的自然保护区要重点监测蝗虫的发 生动态, 以免发生大规模的蝗灾。同时, 加强宣传 教育, 提高民众的科学防范意识和处置能力, 形成 全民参与氛围, 及时发现并处理已形成自然群落的 外来物种, 杜绝危险的外来物种饲养和放生, 使得 外来物种在可控阈值内最大程度为当地居民带来 经济利益。
5.4 因地制宜，加强流域分段式管理，生态保护与 农业发展协同推进

由于黄河流域自身的特异性，既是我国重要的 生态屏障, 也是农业生产的主要区域。因此，防治 生物入侵既要考虑生态环境, 又要关注农业生产, 而不能简单地把防治措施应用于黄河的全部流域, 避免“一刀切”的管理方式。

根据习近平总书记的指导思想，生物入侵的治 理也要从实际出发, 注重生态环境的保护。在整体 流域上统筹谋划，上、中、下游和干支流协同推进 治理。同时，流域内进行分段式管理，将黄河流域 治理划分责任区至各个州县，从排查、引种到监管、 治理都有相对应的部门负责。还应建立相关的研究 站以供实时监测，从而更好地把各个流域的特点和 当地入侵现状相结合, 为黄河流域生态保护提出科 学有效的治理办法。

黄河流域农业生态复杂，类型多样，而黄河流 域上、中、下游在农林牧副渔业上的发展各有特点, 在进行防治过程中，应因地制宜，针对发生情况采 取相应的预防或治理措施。黄河上游地区以牧业发 展为主，辅以旱作农业，过度放牧给外来毒杂草提 供了入侵机会。因此应提前进行杂草入侵的风险预 估，以预防为主，避免大面积危害农田和草地生态 系统，同时应加强改善草地退化现象，维持生态平 衡。而黄河中下游地区是重要的农业发展区域，受 自然和人为因素影响，入侵生物在该地区农田生态 系统中发生种类较多，但多数还处于潜伏阶段，尚 未暴发成灾, 应重点以监测为主, 辅助进行针对性 防治，为促进黄河全流域高质量发展奠定基石。

\section{参考文献}

Blossey B, Nötzold R (1995) Evolution of increased competitive ability in invasive nonindigenous plants: A hypothesis. Journal of Ecology, 83, 887-889.

Cai FJ, Wu ZJ, He N, Ning L, Huang CM (2010) Research progress in invasion ecology of Procambarus clarkia. Chinese Journal of Ecology, 29, 124-132. (in Chinese with English abstract) [蔡风金, 武正军, 何南, 宁蕾, 黄乘明 (2010) 克氏原鳌虾的入侵生态学研究进展. 生态学杂志, 29, 124-132.]

Cao YQ, Zhang TT, Wang XF, Xu D, Lu L (2014) Revision and application of the PDSI index in the Yellow River Basin. Resources Science, 36, 1810-1815. (in Chinese with English abstract) [曹永强, 张亭亭, 王学风, 徐丹, 路璐 (2014) 黄河流域帕尔默干旱指数的修正及应用. 资源科 
学, 36, 1810-1815.]

Chen JC, Shen GM, Meng SL, Qu JH (2010) Investigation and study on the aquaculture alien species in the lower reaches of Yangtze River. Chinese Agricultural Science Bulletin, 26, 315-319. (in Chinese with English abstract) [陈家长, 沈公 铭, 孟顺龙, 篗建宏 (2010) 长江下游流域水产养殖外来 物种调查研究. 中国农学通报, 26, 315-319.]

Chen MM, Ke YH, Bai JH, Li P, Liu MY, Gong ZN, Zhou DM (2020) Monitoring early stage invasion of exotic Spartina alterniflora using deep-learning super-resolution techniques based on multisource high-resolution satellite imagery: A case study in the Yellow River Delta, China. International Journal of Applied Earth Observations and Geoinformation, 92, 1-14.

Chen Y, Zhang KY, Chen XD, Liao YH, Song BT, Huang H, Wang XC (2020) Ecological protection and high-quality development in the Yellow River basin. Regional Economic Review, (1), 8-22. (in Chinese) [陈耀, 张可云, 陈晓东, 廖元和, 宋丙涛, 黄寰, 王喜成 (2020) 黄河流域生态保 护和高质量发展. 区域经济评论, (1), 8-22.]

Chen YP, Fu BJ (2019) On the construction of ecological civilization in the Yellow River Basin. Chinese Science News, 2019-12-20. (in Chinese) [陈怡平, 傅伯杰 (2019) 关于黄河流域生态文明建设的思考. 中国科学报, 2019-12-20.]

Chu D, Liu KC, Zhang Z, Yu Y (2009) Current status of biological invasion in Shandong Province and its management strategies: Thoughts on invasion of alien species Hyphantria cunea (Drury). Shandong Agricultural Sciences, 43, 121-124. (in Chinese with English abstract) [禇栋, 刘开昌, 张正, 于毅 (2009) 山东省生物入侵的现 状及其防控对策一由入侵物种美国白蛾大暴发引发的 思考. 山东农业科学, 43, 121-124.]

Deng LJ, Zou ZM (2012) Growth regularity, seed propagation and control effect of Bidens pilosa. Southwest China Journal of Agricultural Sciences, 25, 1460-1463. (in Chinese with English abstract) [邓玲姣, 邹知明 (2012) 三叶鬼针草生 长、繁殖规律与防除效果研究. 西南农业学报, 25, 1460-1463.]

Díaz S, Settele J, Brondízio E, Ngo $\mathrm{H}$, Guèze $\mathrm{M}$, Agard J, Arneth A, Balvanera P, Brauman K, Butchart S, Chan K, Garibaldi L, Ichii K, Liu J, Subrmanian S, Midgley G, Miloslavich P, Molnár Z, Obura D, Pfaff A, Polasky S, Purvis A, Razzaque J, Reyers B, Chowdhury R, Shin Y, Visseren-Hamakers I, Wilis K, Zayas C (2019) Summary for policymakers of the global assessment report on biodiversity and ecosystem services of the Intergovernmental Science-Policy Platform on biodiversity and ecosystem services. Natural Resources \& Environment, 45, 665-686.

Ding JQ (2002) The mechanism of biological invasion and its effect on ecosystem safety. Review of China Agricultural Science and Technology, 4(4), 16-20. (in Chinese with English abstract) [丁建清 (2002) 外来生物的入侵机制及 其对生态安全的影响. 中国农业科技导报, 4(4), 16-20.]

Ding JQ, Richard NM, Lu P, Ren MX, Huang HW (2008)
China's booming economy is sparking and accelerating biological invasions. BioScience, 58, 317-324.

Du WB, Ye YZ, Zhang XY, Yuan ZL (2002) Study on the foreing harmful plant in Henan. Henan Science, 21, 52-55. (in Chinese with English abstract) [杜卫兵, 叶永忠, 张秀 艳, 袁志良 (2002) 河南主要外来有害植物的初步研究. 河南科学, 21, 52-55.]

Feng HC, Chen XR, Li ZW, Han ZJ (2015) Harm of aquatic plant invasion on aquatic ecosystem. Fishery Guide to be Rich, (3), 28-30. (in Chinese) [冯洪超, 陈秀荣, 李振武, 韩志娟 (2015) 水生植物入侵对水生态系统的危害. 渔 业致富指南, (3), 28-30.]

Frankow-Lindberg BE, Brophy C, Collins RP, Connolly J (2009) Biodiversity effects on yield and unsown species invasion in a temperate forage ecosystem. Annals of Botany, 103, 913-921.

Gao Y, Liu JY, Zhang TT, Feng GP, Zhang T, Yang G, Zhuang $P$ (2017) Escaped aquacultural species promoted the alien species invasion in the Yangtze River: A case study of sturgeons. Chinese Journal of Ecology, 36, 1739-1745. (in Chinese with English abstract) [高宇, 刘鉴毅, 张婷婷, 冯 广朋, 张涛, 杨刚, 庄平 (2017) 水产养殖逃逸对长江外 来种入侵影响：以鲟鱼为例。生态学杂志，36, 1739-1745.]

Gao YL, Lian Y, Zhu TQ (2004) Thoughts on the conservation of fish resources in the Yellow River. Yellow River, 26(10), 12-14. (in Chinese) [高玉玲, 连煜, 朱铁群 (2004) 关于 黄河鱼类资源保护的思考. 人民黄河, 26(10), 12-14.]

Geng MQ (2020) Analysis on the comprehensive improvement project of the Yellow River control and protection in Henan Province. Yellow River, 42(9), 76-80. (in Chinese with English abstract) [耿明全 (2020) 黄河下游河南段治理与 保护综合提升工程分析. 人民黄河, 42(9), 76-80.]

Guo YL, Ding SY, Su S, Lu XL, Yuan XW, Guo JJ, Li QX (2013) Distribution patterns of alien herbs in the Yiluo River basin. Acta Ecologica Sinica, 33, 5438-5447. (in Chinese with English abstract) [郭屹立, 丁圣彦, 苏思, 卢训令, 苑 晓雯, 郭静静, 李乾玺 (2013) 伊洛河流域外来草本植物 分布格局. 生态学报, 33, 5438-5447.]

Han GX, Li YZ, Yu JB, Xu JW, Wang GM, Zhang ZD, Mao PL, Liu YH (2011) Evolution process and related driving mechanisms of Yellow River Delta since the diversion of Yellow River. Chinese Journal of Applied Ecology, 22, 467-472. (in Chinese with English abstract) [韩广轩, 栗云 召, 于君宝, 许景伟, 王光美, 张志东, 毛培利, 刘玉虹 (2011) 黄河改道以来黄河三角洲演变过程及其驱动机 制. 应用生态学报, 22, 467-472.]

Hou DL, He DJ, Hong W, You WB, Wu LY, Ji ZR, Xiao SH (2015) Influence of invasive Spartina alterniflora on soil ecosystem in coastal wetland. Wetland Science \& Management, 11(4), 67-72. (in Chinese with English abstract) [侯栋梁，何东进，洪伟，游巍斌，巫丽芸，纪志 荣, 肖石红 (2015) 入侵种互花米草影响我国滨海湿地 土壤生态系统的研究进展. 湿地科学与管理, 11(4), 67-72.] 
Huang W, Siemann E, Wheeler SG, Zou JW, Carrillo J, Ding JQ (2010) Resource allocation to defense and growth are driven by different responses to generalist and specialist herbivory in an invasive plant. Journal of Ecology, 98, 1157-1167.

Huang WY, Cai T, Gong HH, Meng XC, Liao ZJ, Guo J (2019) Comparative study on biomass in water hyacinth and several raw water plants. Journal of China Three Gorges University (Natural Sciences), 41, 108-112. (in Chinese with English abstract) [黄文邸, 蔡涛, 龚姮姮, 蒙雪婵, 廖照江, 郭坚 (2019) 凤眼莲与几种水生植物所含生物质的比较研究. 三峡大学学报(自然科学版), 41, 108-112.]

Jack CN, Friesen ML (2019) Rapid evolution of Medicago polymorpha during invasion shifts interactions with the soybean looper. Ecology and Evolution, 9, 10522-10533.

Jiang H, Xie SG, Zhao WQ, Chang JB (2007) Changes of fish assemblages after construction of Ertan Reservoir in Yalongjiang River. Acta Hydrobiologica Sinica, 13, 532-539. (in Chinese with English abstract) [蒋红, 谢嗣光, 赵文谦，常剑波 (2007) 二滩水电站水库形成后鱼类种 类组成的演变. 水生生物学报, 13, 532-539.]

Jiang WL (2010) Study on the adaptive strategy for China's water resources problems. Science and Society, (2), 24-29. (in Chinese) [姜文来 (2010) 应对我国水资源问题适应性 战略研究. 科学与社会, (2), 24-29.]

Jiang WZ (2014) Study on the distribution, growth and control techniques of mud snails in the Yellow River Delta. Hebei Fisheries, (4), 11-12. (in Chinese) [蒋万钊 (2014) 黄河三 角洲泥螺分布、生长规律的演变及控制技术研究. 河北渔 业, (4), 11-12.]

Jiang YY, Liu J, Xie MC, Li YH, Yang JJ, Zhang ML, Qiu K (2019) Observation on law of diffusion damage of Spodoptera frugiperda in China in 2019. Plant Protection, 45(6), 10-19. (in Chinese with English abstract) [姜玉英, 刘杰, 谢茂昌, 李亚红, 杨俊杰, 张曼丽, 邱坤 (2019) 2019年我国草地贪夜蛾扩散为害规律观测. 植物保护, 45(6), 10-19.]

Ju RT, Li H, Shih CJ, Li B (2012) Progress of biological invasions research in China over the last decade. Biodiversity Science, 20, 581-611. (in Chinese with English abstract) [鞠瑞亭, 李慧, 石正人, 李博 (2012) 近十年中 国生物入侵研究进展. 生物多样性, 20, 581-611.]

Keane RM, Crawley MJ (2002) Exotic plant invasions and the enemy release hypothesis. Trends in Ecology \& Evolution, $17,164-170$.

Li B, Liao CZ, Gao L, Luo YQ, Ma ZJ (2004) Strategic management of water hyacinth (Eichhornia crassipes), an invasive alien plant. Journal of Fudan University (Natural Science), 43, 267-274. (in Chinese with English abstract) [李博, 廖成章, 高雷, 骆亦其, 马志军 (2004) 入侵植物 凤眼莲管理中的若干生态学问题. 复旦学报(自然科学 版), 43, 267-274.]

Li C, Xie F (2004) Invasion of bullforg (Rana catesbeinan Show) in China and its management strategies. Chinese Journal of Applied and Environmental Biology, 10, 95-98. (in Chinese with English abstract) [李成, 谢锋 (2004) 牛 蛙入侵新案例与管理对策分析. 应用与环境生物学报, 10, 95-98.]

Li CK, Zhang YX, Jia YX, Zhang GY (2011) Research on investigation into the alien invasive biological species in Henan Province and measure for it. Journal of Henan Agricultural University, 45, 672-677. (in Chinese with English abstract) [李长看, 张云霞, 贾元翔, 张光宇 (2011) 河南省生物入侵种调查及对策研究. 河南农业大 学学报, 45, 672-677.]

Li F, Zhang JJ, Yuan YF, Feng H, Zhang JY, Yang XZ (2008) Present situation and problems on fish introduction in Yellow River system. Journal of Anhui Agricultural Sciences, 36, 15024-15026. (in Chinese with English abstract) [李芳, 张建军, 袁永锋, 冯慧, 张军燕, 杨兴中 (2008) 黄河流域鱼类引种现状及存在问题. 安徽农业科 学, 36, 15024-15026.]

Li HJ, Yuan YF, Li YD, Zhang JJ (2009) Research progress of aquatic biological resources in the Yellow River basin. Hebei Fisheries, (10), 1-3. (in Chinese) [李红娟, 袁永锋, 李引娣, 张建军 (2009) 黄河流域水生生物资源研究进 展. 河北渔业, (10), 1-3.]

Li KM, Li X, Wang CY, Qiao YJ (2013) Research on the environmental effect caused by climate change in the source region of the Yellow River. Journal of Glaciology and Geocryology, 35, 1183-1192. (in Chinese with English abstract) [李开明, 李绚, 王翠云, 乔艳君 (2013) 黄河源 区气候变化的环境效应研究. 冰川冻土, 35, 1183-1192.]

Li L, Lin YB, Liu C (2018) Review on biological characteristics and management strategies of Eichhornia crassipes (Mart.) Solms. Journal of Anhui Agricultural Sciences, 46(3), 60-62. (in Chinese with English abstract) [李礼, 林艺滨, 刘灿 (2018) 入侵植物凤眼莲的生物学 特性及生态管理对策. 安徽农业科学, 46(3), 60-62.]

Li ZY, Xie Y (2002) Alien Invasive Species in China. China Forestry Publishing House, Beijing. (in Chinese) [李振宇, 解炎 (2002) 中国外来入侵种. 中国林业出版社, 北京.]

Lin Y, Dai ZC, Si CC, Du DL (2008) A study survey and prospect on invasive condition and invasive mechanism of Lantana camara L. Journal of Hainan Normal University (Natural Science), 26, 87-93. (in Chinese with English abstract) [林英，戴志聪，司春灿，杜道林 (2008) 入侵植 物马缨丹(Lantana camara)入侵状况及入侵机理研究概况 与展望. 海南师范大学学报(自然科学版), 26, 87-93.]

Liu F (2015) Preliminary Study of Pollution, Degradation and Remediation in Aquatic Ecosystem of Yellow River Delta Wetland. PhD dissertation, Ocean University of China, Qingdao. (in Chinese with English abstract) [刘峰 (2015) 黄河三角洲湿地水生态系统污染、退化与湿地修复的初 步研究. 博士学位论文, 中国海洋大学, 青岛.]

Liu QN, Liu JZ, Liu JT, Meng XD (2006) Preliminary study on the alien invasive and harmful biotics in the Yellow River Delta. Journal of Shandong Agricultural University (Natural Science Edition), 37, 581-585. (in Chinese with English abstract) [刘庆年, 刘俊展, 刘京涛, 孟向东 (2006) 黄河 
三角洲外来入侵有害生物的初步研究. 山东农业大学学 报(自然科学版), 37, 581-585.]

Liu T, Liu YW, Wang YJ, Zou Y, Wu YY, Li QC, Song AH (2018) Biological characteristic of Bullacta exarata population in intertidal zone of Yellow River Delta, China. Fisheries Science \& Technology Information, 45, 347-351. (in Chinese with English abstract) [刘童, 刘元文, 王英俊, 邹琰, 吴莹芗, 李戈楚, 宋爱环 (2018) 黄河口三角洲潮 间带泥螺群体的生物学特性研究. 水产科技情报, 45, 347-351.]

Lu F, Wang X (2017) General situation of the introduction and genetic diversity of Spartina alterniflora. Journal of Shandong Forestry Science and Technology, 47, 107-112. (in Chinese with English abstract) [路峰, 王昕 (2017) 互 花米草引种及遗传多样性研究进展. 山东林业科技, 47, 107-112.]

Lu P, Liang H, Wang HY, Bai YM, Gao FJ, Song G, Wu Y, Tian QY (2010) Research progress on exotic invasive weed Amaranthus retroflexus. Chinese Journal of Ecology, 29, 1662-1670. (in Chinese with English abstract) [鲁萍, 梁慧, 王宏燕, 白雅梅, 高凤杰, 宋戈, 吴岩, 田秋阳 (2010) 外来入侵杂草反枝苋的研究进展. 生态学杂志, 29 , 1662-1670.]

Niu BL (1996) Fifty years of harnessing the lower reaches of the Yellow River. Journal of Yellow River Conservancy Technical Institute, 9(3), 5-7. (in Chinese) [钮本良 (1996) 黄河下游治理五十年述要. 黄河水利教育, 9(3), 5-7.]

Pan HJ, Tian JY (2001) Alien harmful plants in Shandong Province. Plant Quarantine, 23(4), 245-246. (in Chinese) [潘怀剑, 田家怡 (2001) 山东省的外来有害植物. 植物 检疫, 23(4), 245-246.]

Pan XY, Geng YP, Alejandro SOSA, Zhang WJ, Li B, Chen JK (2007) Invasive Alternanthera philoxeroides: Biology, ecology and management. Acta Phytotaxonomica Sinica, 13, 884-900. (in Chinese with English abstract) [潘晓云, 耿宇 鹏, Alejandro SOSA, 张文驹, 李博, 陈家宽 (2007) 入侵 植物喜早莲子草—生物学、生态学及管理. 植物分类学 报, 13, 884-900.]

Qiu JS, Zhang NN, Tian MJ, Xu ZZ, Ban QM (2019) Influence of invasive alien species on people's livelihood and ecology in North \& South Pan River and Hongshui River Valley. Guizhou Forestry Science and Technology, 47(4), 18-22. (in Chinese with English abstract) [邱建生, 张念念, 田茂娟, 徐泽洲, 班启明 (2019) 外来入侵物种对南北盘江及红 水河流域民生和生态的影响研究. 贵州林业科技, 47(4), 18-22.]

Ren MX, Zhang QG (2009) The relative generality of plant invasion mechanisms and predicting future invasive plants. Weed Research, 49, 449-460.

Stokstad E (2017) New crop pest takes Africa at lightning speed. Science, 356, 473-474.

Su YR, Liu XH, Zhang DL, Li S (2011) Screening and analysis of pre-harvest sprouting resistant germplasm from Aegilops tauschiis in the middle reaches of the Yellow River. Journal of Plant Genetic Resources, 12, 1004-1009. (in Chinese with English abstract) [苏亚芯, 刘新浩, 张大乐, 李锁 (2011) 黄河中游地区节节麦抗穗发芽的鉴定与分析. 植 物遗传资源学报, 12, 1004-1009.]

Tian CY, Li JZ, Xu JW, Zheng XJ, Zhu CS (2005) Studies on the alien invasive plants and their control in Henan Province. Journal of Henan Agricultural Sciences, 34, 31-34. (in Chinese with English abstract) [田朝阳, 李景照, 徐景文, 郑晓军, 朱长山 (2005) 河南外来入侵植物及防 除研究. 河南农业科学, 34, 31-34.]

Wan FH, Guo JY, Wang DH (2002) Alien invasive species in China: Their damages and management strategies. Biodiversity Science, 10, 119-125. (in Chinese with English abstract) [万方浩, 郭建英, 王德辉 (2002) 中国外来入侵 生物的危害与管理对策. 生物多样性, 10, 119-125.]

Wang FF, Yan JG, Ma X, Qiu DD, Cui BS (2020) Decomposition characteristics of vegetation litter of Suaeda salsa and Spartina alterniflora in saltmarsh of the Yellow River Estuary, China. Journal of Natural Resources, 35, 480-492. (in Chinese with English abstract) [汪方芳, 间家 国, 马旭, 邱冬冬, 崔保山 (2020) 黄河口盐沼湿地盐地 碱蓬和互花米草调落物的分解特征. 自然资源学报, 35, 480-492.]

Wang MN, Dai ZC, Qi SS, Wang XY, Du DL (2014) Main hypotheses and research progress of invasive mechanism of alien plants. Jiangsu Agricultural Sciences, 42, 378-382. (in Chinese with English abstract) [王明娜, 戴志聪, 祁珊珊, 王晓荣, 杜道林 (2014) 外来植物入侵机制主要假说及 其研究进展. 江苏农业科学, 42, 378-382.]

Wang N, Yuan ML, Chen H, Li ZZ, Zhang MX (2019) Effects of drought stress and rewatering on growth and physiological characteristics of invasive Aegilops tauschii seedlings. Acta Prataculturae Sinica, 28, 70-78. (in Chinese with English abstract) [王宁，袁美丽，陈浩，李真真，张铭 金金 (2019) 干旱胁迫及复水对入侵植物节节麦幼苗生长 及生理特性的影响. 草业学报, 28, 70-78.]

Wang W, Xia RB (2019) On the reasons for the increase of floods in the Yellow River during the little ice age in Ming and Qing dynasties-Based on the perspective of climate change. Journal of Western, (5), 42-45. (in Chinese) [王威, 夏如兵 (2019) 试论明清小冰期黄河水患增多的原因 基于气候变化的视角. 西部学刊, (5), 42-45.]

Wang Y, Zhang YZ (1998) Human activities and the influence of the Yellow River cutoff and coastal environment. Journal of Nanjing University (Natural Sciences), 44(3), 3-5. (in Chinese with English abstract) [王颖, 张永战 (1998) 人类 活动与黄河断流及海岸环境影响. 南京大学学报(自然科 学版), 44(3), 3-5.]

Weiskopf SR, Rubenstein MA, Crozier LG, Gaichas S, Griffis R, Halofsky JE, Hyde KJW, Morelli TL, Morisette JT, Muñoz RC, Pershing AJ, Peterson DL, Poudel R, Staudinger MD, Sutton-Grier AE, Thompson L, Vose J, Weltzin JF, Whyte KP (2020) Climate change effects on biodiversity, ecosystems, ecosystem services, and natural resource management in the United States. Science of the Total Environment, 733, 1-13. 
White LF, Shurin JB (2007) Diversity effects on invasion vary with life history stage in marine macroalgae. Oikos, 116, 1193-1203.

Wu H, Ding JQ (2014) Recent progress in invasion ecology. Chinese Science Bulletin, 59, 438-448. (in Chinese with English abstract) [吴吴, 丁建清 (2014) 入侵生态学最新 研究动态. 科学通报, 59, 438-448.]

Wu T, Li JX, Dai J, Wang RQ (2007) Floristic characteristics and spatial distribution patterns of alien plants in Shandong Province. Chinese Journal of Ecology, 26, 489-494. (in Chinese with English abstract) [吴䀐, 李俊祥, 戴洁, 王仁 卿 (2007) 山东省外来植物的区系特征及空间分布. 生 态学杂志, 26, 489-494.]

Wu ZN, Huang SQ, Di DY, Wang HL (2019) Study on the value and spatial distribution of water resources in agricultural system of the Yellow River Basin. Journal of Irrigation and Drainage, 38, 93-100. (in Chinese with English abstract) [吴泽宁, 黄硕俏, 狄丹阳, 王慧亮 (2019) 黄河流域农业系统水资源价值及其空间分布研 究. 灌溉排水学报, 38, 93-100.]

Xie BH, Han GX, Qiao PY, Guan B (2019) Effects of mechanical and chemical control on invasive Spartina alterniflora in the Yellow River Delta, China. PeerJ, 7, e7665.

Xie XF, Sun XM, Wu T, Jiang GJ, Pu LJ, Xiang Q (2020) Impact of Spartina alterniflora invasion on coastal wetland ecosystem: Advances and prospects. Chinese Journal of Applied Ecology, 31, 1-11. (in Chinese with English abstract) [解雪峰, 孙晓敏, 吴涛, 蒋国俊, 誉励杰, 项琦 (2020) 互花米草入侵对滨海湿地生态系统影响研究进 展. 应用生态学报, 31, 1-11.]

Xu CY, Zhang WJ, Lu BR, Chen JK (2001) Progress in studies on mechanisms of biological invasion. Biodiversity Science, 9, 430-438. (in Chinese with English abstract) [徐承远, 张 文驹, 卢宝荣, 陈家宽 (2001) 生物入侵机制研究进展. 生物多样性, 9, 430-438.]

Yan CR, Mei XR, He WQ, Yang J (2006) Status and characteristics of conservation tillages in Yellow River Basin. Journal of Agro-Environment Science, 25, 844-847. (in Chinese with English abstract) [严昌荣, 梅旭荣, 何文 清, 杨捷 (2006) 黄河流域保护性耕作技术的应用现状 及特点. 农业环境科学学报, 25, 844-847.]

Yan HQ (2009) The influence of the diversion of the Yellow River on the Yellow River Delta in 1855. Chinese Literature and History, 29(4), 17-20. (in Chinese) [阎海青 (2009) 1855年黄河改道对黄河三角洲的影响. 文史知识, 29(4), 17-20.]

Yan SL, Huangfu CH, Li G, Zuo ZJ, Ma J, Yang DL (2011) Effects of replacement control with four forage species on bacterial diversity of soil invaded by Flaveria bidentis. Chinese Journal of Plant Ecology, 35, 45-55. (in Chinese with English abstract) [间素丽, 皇甫超河, 李刚, 左照江, 马杰, 杨殿林 (2011) 四种牧草植物替代控制对黄顶菊
入侵土壤细菌多样性的影响. 植物生态学报, 35, 45-55.]

Yang LJ, Ma XC, Jia JJ, Yan J, Luan ZD (2020) Impacts of channel shifts and interannual sediment load reducing of the Yellow River on the grain size characteristics of sediments in the Shandong mud wedge over the past 100 years. Haiyang Xuebao, 42(1), 78-89. (in Chinese) [杨立建, 马小 川, 贾建军, 阎军, 奕振东 (2020) 近百年来黄河改道及 输沙量变化对山东半岛泥质楔沉积物粒度特征的影响. 海洋学报, 42(1), 78-89.]

Yang PY, Zhu XM, Guo JF, Wang ZY (2019) Strategy and advice for managing the fall armyworm in China. Plant Protection, 45(4), 1-6. (in Chinese with English abstract) [杨普云, 朱晓明, 郭井菲, 王振营 (2019) 我国草地贪夜 蛾的防控对策与建议. 植物保护, 45(4), 1-6.]

Yang W, Jeelanib N, Zhu HZ, Luo YQ, Cheng XL, An SQ (2018) Alterations in soil bacterial community in relation to Spartina alterniflora Loisel. invasion chronosequence in the eastern Chinese coastal wetlands. Applied Soil Ecology, 135, 38-43.

Yu ZR, Dou SZ, Zhao PC, Liu GC, Zhang C, Pei F (2004) Relationship between changes of Dongping Lake and shifting of the Yellow River in Shandong Province. Journal of Palaeogeography, 6, 469-479. (in Chinese with English abstract) [喻宗仁, 窦素珍, 赵培才, 刘桂成, 张成, 裴放 (2004) 山东东平湖的变迁与黄河改道的关系. 古地理学 报, 6, 469-479.]

Zhang CM, Zhang CF, Zhu QQ, Jia YX, Luo X, Zhang SR, Li Y, Li T (2016) Physiological response and subcellular distribution of copper in Lantana camara L. Journal of Agro-Environment Science, 35, 21-28. (in Chinese with English abstract) [张春梅, 张长锋, 朱青青, 贾永霞, 罗 弦, 张世熔, 李云, 李婷 (2016) 马缨丹对铜的生理响应 及亚细胞分布特征. 农业环境科学学报, 35, 21-28.]

Zhang DC, Zheng JL (2019) Preliminary study on invasion of alien fish species after construction of hydropower projects. Yangtze River, 50(2), 83-89. (in Chinese with English abstract) [张登成, 郑娇莉 (2019) 水电工程建设前后外 来鱼类入侵问题初步研究. 人民长江, 50(2), 83-89.]

Zhang GX, Deng W, He Y (2004) Groundwater crisis and sustainable agricultural development in North China. Arid Land Geography, 27, 437-441. (in Chinese with English abstract) [章光新, 邓伟, 何岩 (2004) 我国北方地下水危 机与可持续农业的发展. 干旱区地理, 27, 437-441.]

Zhang HW (2020) Problems and countermeasures in the protection and development of the Yellow River basin. Yellow River, 42(3), 1-10. (in Chinese with English abstract) [张红武 (2020) 黄河流域保护和发展存在的问 题与对策. 人民黄河, 42(3), 1-10.]

Zhang HX (2010) The ecological threat of alien turtle or turtle category to original types in Yellow River Basin. Modern Agricultural Sciences and Technology, 17, 328-330. (in Chinese with English abstract) [张红星 (2010) 黄河中游 流域外来龟、鳖类对原有种类的生态威胁. 现代农业科 
技, 17, 328-330.]

Zhang LW, Zhao YJ, Wang AD, Feng GH, Song JB, Xie BH, Han GX, Lü JZ, Zhu SY (2018) Genetic variation and spread of Spartina alternifora in the Yellow River Delta. Wetland Science, 16, 1-8. (in Chinese with English abstract) [张俪文, 赵亚杰, 王安东, 冯光海, 宋建涁, 谢宝华, 韩 广轩, 吕卷章, 朱书玉 (2018) 黄河三角洲互花米草的遗 传变异和扩散. 湿地科学, 16, 1-8.]

Zhang PJ, Zhao LQ, Liang CX, Zhang GL, Zhang QQ, Yue L, Xu BY, Yang J, Zhang PQ, Qing H (2019) Risk assessment of alien invasive plants in Inner Mongolia. Chinese Journal of Ecology, 38, 1973-1981. (in Chinese with English abstract) [张璞进, 赵利清, 梁晨霞, 张国龙, 张迁迁, 岳 丽, 徐步云, 杨劼, 张培青, 清华 (2019) 内蒙古外来植 物入侵风险评价. 生态学杂志, 38, 1973-1981.]

Zhang XL (2005) The Environmental Change and Degradation of Modern Yellow River Delta Coastal Wetland. PhD dissertation, Ocean University of China, Qingdao, Shandong. (in Chinese with English abstract) [张晓龙 (2005) 现代黄河三角洲滨海湿地环境演变及退化研究. 博士学位论文, 中国海洋大学, 山东青岛.]

Zhang XY (2015) The relationship between the Yellow River flood and the ecological environment change of the Yellow River Delta in the Qing Dynasty - A case study of the Dongying section of the Yellow River. China Water Transport, 15(10), 192-194. (in Chinese) [张小云 (2015) 清代黄河水患与黄河三角洲生态环境变迁的关系一以 黄河东营段为例. 中国水运, 15(10), 192-194.]

Zhao HH, Tian JY, Cheng JG, Xia JB, Li Y, Guan YP (2011) Distribution of alien invasive pest species and its comprehensive control in Yellow River Delta. Journal of Binzhou University, 27(6), 31-36. (in Chinese with English abstract) [赵怀浩, 田家怡, 程建光, 夏江宝, 李媛, 管银 屏 (2011) 黄河三角洲地区外来入侵有害生物的种类分 布与防治. 滨州学院学报, 27(6), 31-36.]

Zhao WX, Song JJ, Yu CY, Liu Y, Liu YW, Guan SG, Yu DD (2017) Research progress on invasion and dispersion of Bullacta exarata in the Yellow River Delta. Ocean Development and Management, 34(S2), 142-147. (in Chinese with English abstract) [赵文溪, 宋静静, 于超勇, 刘芗, 刘元文, 官曙光, 于道德 (2017) 黄河三角洲区域 泥螺入侵与扩散研究进展. 海洋开发与管理, 34(S2), 142-147.]

Zheng LM (2007) Grain safety in water diversion areas in lower reaches of the Yellow River. China Water Resources, (13), 46-48. (in Chinese with English abstract) [郑利民 (2007) 黄河下游引黄灌区粮食安全问题浅析. 中国水利, (13), 46-48.]

Zheng ZX, Wang R, Zhang FJ, Wan FH (2018) The geographic distribution pattern and spatiotemporal dynamic of the invasive alien plant Flaveria bidentis (Asteraceae) in China. Journal of Biosafety, 27, 295-299. (in Chinese with English abstract) [郑志金金, 王瑞, 张风娟, 万方浩 (2018) 外来入 侵植物黄顶菊在我国的地理分布格局及其时空动态. 生 物安全学报, 27, 295-299.]

Zhou ZS, Guo JY, Wan FH (2015) Review on management of Ambrosia artemisiifolia using natural enemy insects. Chinese Journal of Biological Control, 31, 657-665. (in Chinese with English abstract) [周忠实, 郭建英, 万方浩 (2015) 利用天敌昆虫治理豚草的研究进展. 中国生物防 治学报, 31, 657-665.]

(责任编委：鞠瑞亭 责任编辑：问文杰)

\section{附录 Supplementary Material}

附录1 黄河流经九省区中的外来入侵植物和入侵动物

Appendix 1 Alien invasive plants and animals in nine provinces of the Yellow River http://www.biodiversity-science.net/fileup/PDF/2020208-1.xlsx

\section{附录2 IUCN公布的最危险入侵物种在黄河九省区的分布情况}

Appendix 2 Distribution of the most dangerous invasive species announced by IUCN in nine provinces along the Yellow River http://www.biodiversity-science.net/fileup/PDF/2020208-2.pdf

\section{附录3 生态环境部公布的重大危害外来物种在黄河九省区的分布情况}

Appendix 3 Distribution of the most harmful alien species announced by Ministry of Ecology and Environment in nine provinces of the Yellow River

http://www.biodiversity-science.net/fileup/PDF/2020208-3.pdf

\section{附录4 凤眼莲在池塘暴发危害场景}

Appendix 4 The outbreak of water hyacinth (Eichhornia crassipes) in ponds http://www.biodiversity-science.net/fileup/PDF/2020208-4.pdf

\section{附录5 居民区附近处于开花期的豚草}

Appendix 5 Ambrosia artemisiifolia in flowering stage near residential area http://www.biodiversity-science.net/fileup/PDF/2020208-5.pdf 
殷万东，吴明可，田宝良，于宏伟，王麒云，丁建清 (2020) 生物入侵对黄河流域生态系统的影响及对策. 生物多样性, 2020, 28 (12): 1533-1545. http://www.biodiversity-science.net/CN/10.17520/biods.2020208

\section{附录2 IUCN公布的最危险入侵物种在黄河九省区的分布情况}

Appendix 2 Distribution of the most dangerous invasive species announced by IUCN in nine provinces along the Yellow River

\begin{tabular}{|c|c|c|c|c|c|c|c|c|c|c|}
\hline \multirow{2}{*}{$\begin{array}{l}\text { 物种 } \\
\text { Species }\end{array}$} & \multicolumn{9}{|c|}{ 分布地点 Distribution area } & \multirow{2}{*}{$\begin{array}{l}\text { 参考文献 } \\
\text { Reference }\end{array}$} \\
\hline & $\begin{array}{l}\text { 青海 } \\
\text { Qinghai }\end{array}$ & $\begin{array}{l}\text { 四川 } \\
\text { Sichuan }\end{array}$ & $\begin{array}{l}\text { 甘肃 } \\
\text { Gansu }\end{array}$ & $\begin{array}{l}\text { 宁夏 } \\
\text { Ningxia }\end{array}$ & $\begin{array}{l}\text { 内蒙古 } \\
\text { Neimong } \\
\text { ol }\end{array}$ & $\begin{array}{l}\text { 山西 } \\
\text { Shanxi }\end{array}$ & $\begin{array}{l}\text { 陕西 } \\
\text { Shaanxi }\end{array}$ & $\begin{array}{l}\text { 河南 } \\
\text { Henan }\end{array}$ & $\begin{array}{l}\text { 山东 } \\
\text { Shan } \\
\text { dong }\end{array}$ & \\
\hline $\begin{array}{l}\text { 红耳彩龟 } \\
\text { Trachemys scripta } \\
\text { elegans }\end{array}$ & $\sqrt{ }$ & $\sqrt{ }$ & $\sqrt{ }$ & $\sqrt{ }$ & $\sqrt{ }$ & $\sqrt{ }$ & $\sqrt{ }$ & $\sqrt{ }$ & $\sqrt{ }$ & $\begin{array}{l}\text { 刘丹等, 2011; 顾 } \\
\text { 丽华, } 2018\end{array}$ \\
\hline $\begin{array}{l}\text { 德国镜鲤 } \\
\text { Cyprinus carpio }\end{array}$ & - & - & - & - & - & - & $\sqrt{ }$ & - & $\sqrt{ }$ & 侯淑敏等, 2016 \\
\hline $\begin{array}{l}\text { 大口黑鲈 } \\
\text { Micropterus } \\
\text { salmoides }\end{array}$ & - & - & - & - & - & - & - & - & $\sqrt{ }$ & $\begin{array}{l}\text { 徐海根和强胜, } \\
2017\end{array}$ \\
\hline $\begin{array}{l}\text { 红罗非鱼 } \\
\text { Oreochromis } \\
\text { mossambicus } \times \text { O. } \\
\text { niloticus }\end{array}$ & - & - & - & - & - & - & - & - & $\sqrt{ }$ & 陆成伟等, 2020 \\
\hline $\begin{array}{l}\text { 虹䲡 } \\
\text { Oncorhynchus } \\
\text { mykiss }\end{array}$ & $\sqrt{ }$ & - & - & - & - & $\sqrt{ }$ & $\sqrt{ }$ & - & $\sqrt{ }$ & $\begin{array}{l}\text { 唐文家和何德奎, } \\
2015\end{array}$ \\
\hline $\begin{array}{l}\text { 蟾胡子鲶 } \\
\text { Clarias batrachus }\end{array}$ & - & - & - & - & - & - & - & - & $\sqrt{ }$ & $\begin{array}{l}\text { 徐海根和强胜, } \\
2017\end{array}$ \\
\hline $\begin{array}{l}\text { 食蚊鱼 } \\
\text { Gambusia affinis }\end{array}$ & $\sqrt{ }$ & $\sqrt{ }$ & $\sqrt{ }$ & $\sqrt{ }$ & $\sqrt{ }$ & $\sqrt{ }$ & $\sqrt{ }$ & $\sqrt{ }$ & $\sqrt{ }$ & 魏洁菲, 2019 \\
\hline $\begin{array}{l}\text { 牛蛙 } \\
\text { Rana catesbiana }\end{array}$ & $\sqrt{ }$ & $\sqrt{ }$ & $\sqrt{ }$ & $\sqrt{ }$ & $\sqrt{ }$ & $\sqrt{ }$ & $\sqrt{ }$ & $\sqrt{ }$ & $\sqrt{ }$ & 周伟等, 2012 \\
\hline $\begin{array}{l}\text { 红火蚁 } \\
\text { Solenopsis invicta }\end{array}$ & - & $\sqrt{ }$ & - & - & - & - & - & - & - & 邹勤等, 2020 \\
\hline $\begin{array}{l}\text { 烟粉風 } \\
\text { Bemisia tabaci }\end{array}$ & $\sqrt{ }$ & $\sqrt{ }$ & $\sqrt{ }$ & $\sqrt{ }$ & $\sqrt{ }$ & $\sqrt{ }$ & $\sqrt{ }$ & $\sqrt{ }$ & $\sqrt{ }$ & 杨益芬等, 2020 \\
\hline $\begin{array}{l}\text { 大米草 } \\
\text { Spartina anglica }\end{array}$ & - & - & - & - & - & - & - & $\sqrt{ }$ & $\sqrt{ }$ & 齐艳红等, 2004 \\
\hline $\begin{array}{l}\text { 黑荆 } \\
\text { Acacia mearnsii }\end{array}$ & - & $\sqrt{ }$ & - & - & - & - & - & - & - & 周伟佳等, 2011 \\
\hline $\begin{array}{l}\text { 荆豆 } \\
\text { Ulex europaeus }\end{array}$ & $\sqrt{ }$ & $\sqrt{ }$ & $\sqrt{ }$ & $\sqrt{ }$ & $\sqrt{ }$ & $\sqrt{ }$ & $\sqrt{ }$ & $\sqrt{ }$ & $\sqrt{ }$ & 蒲芝谷等, 1981 \\
\hline $\begin{array}{l}\text { 乳浆大戟 } \\
\text { Euphorbia Esula }\end{array}$ & $\sqrt{ }$ & $\sqrt{ }$ & $\sqrt{ }$ & $\sqrt{ }$ & $\sqrt{ }$ & $\sqrt{ }$ & $\sqrt{ }$ & $\sqrt{ }$ & $\sqrt{ }$ & 田兰婷等, 2016 \\
\hline $\begin{array}{l}\text { 银合欢 } \\
\text { Leucaena } \\
\text { leucocephala }\end{array}$ & - & $\sqrt{ }$ & - & - & - & - & - & $\sqrt{ }$ & $\sqrt{ }$ & 李登峰等, 2020 \\
\hline $\begin{array}{l}\text { 凤眼莲 } \\
\text { Eichhornia } \\
\text { crassipes }\end{array}$ & - & $\sqrt{ }$ & - & - & - & - & - & $\sqrt{ }$ & $\sqrt{ }$ & 秦智雅等, 2016 \\
\hline
\end{tabular}

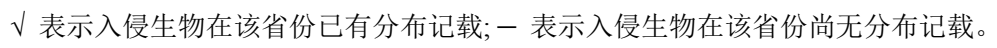

$\sqrt{ }$ indicates that this invasive species has been recorded in this province; - indicates that this invasive species has not been recorded in this province.

\section{参考文献}

Gu LH (2018) Ecological killer-Brazilian tortoise. Environment and Development, 30, 188-189. (in Chinese with English abstract) [顾丽华 (2018) 
殷万东，吴明可，田宝良，于宏伟，王麒云，丁建清 (2020) 生物入侵对黄河流域生态系统的影响及对策. 生物多样性, 2020, 28 (12): 1533-1545. http://www.biodiversity-science.net/CN/10.17520/biods.2020208

生态杀手——巴西龟. 环境与发展, 30, 188-189.]

Hou SM, Li WP, Wang YC, Wen SE, Li HB, Gao Z (2016) The current situation of aquatic animals invasion of Shaanxi stretch of the Yellow River. Journal of Northwest University (Natural Science Edition), 46, 82-86. (in Chinese with English abstract) [侯淑敏, 李维平，王益昌，问思恩， 李海滨, 高志 (2016) 黄河陕西段水生动物入侵现状分析. 西北大学学报(自然科学版), 46, 82-86.]

Li DF, Feng QH, Hu ZD, Xu JR (2020) Comparative study on photosynthetic physiological and chlorophyll fluorescence characteristics of Leucaena leucocephala in wet and dry season, Jinsha River dry-hot valley, China. Acta Ecologica Sinica, 40, 4105-4113. (in Chinese with English abstract) [李登峰, 冯秋红, 胡宗达, 徐静茹 (2020) 金沙江干热河谷新银合欢(Leucaena leucocephala)的光合与苂光特征干湿季对比研究. 生态学报, 40, 4105-4113.]

Liu D, Shi HT, Liu YX, Wang JC, Gong SP, Wang J, Shen L (2011) Investigation on the distribution of red eared turtle in China. Bulletin of Biology, 46(6)，18-21. (in Chinese) [刘丹, 史海涛, 刘宇翔, 汪继超, 龚世平, 王剑, 沈兰 (2011) 红耳龟在我国分布现状的调查. 生物学通报, $46(6), 18-21$.

Lu CW (2014) Effects of Environmental Factors on the Growth of Red Tilapia and Sex Determination. Master's dissertation, Fuzhou University, Fuzhou. (in Chinese with English abstract) [陆成伟 (2014) 环境因子对红罗非鱼生长及性别决定的影响研究. 硕士学位论文, 福州大学, 福州.]

Pu ZG, Jiang XW, Jia KK, Xie QT (1981) Preliminary test on the content of H-resistant substance in seeds and leaves of Vitex negundo. Forensic Science and Technology, 6, 12-14. (in Chinese) [蒲芝谷, 蒋心文, 贾康康, 谢其天 (1981) 对我省荆豆种子和叶子含抗H物质的初步试验. 刑事技术, 6, 12-14.]

Qi YH, Zhao YH, Yin XQ (2004) Ecological distribution of biological invasion in China. Ecology and Environmental Sciences, 13, 414-416. (in Chinese with English abstract) [齐艳红，赵映慧，殷秀琴 (2004) 中国生物入侵的生态分布. 生态环境, 13, 414-416.]

Qin ZY, Tao JY, Hu C, Ruan AD (2016) Distribution, influence and control measures of Eichhornia crassipes in China. Journal of Anhui Agricultural Sciences, 44, 81-84. (in Chinese with English abstract) [秦智雅, 陶景怡, 胡辰, 阮爱东 (2016) 我国水域水葫芦的分布·影 响·防治措施. 安徽农业科学, 44, 81-84.]

Tang WJ, He DK (2015) Investigation on alien fishes in Qinghai Province, China (2001-2014). Journal of Lake Sciences, 27, 502-510. (in Chinese with English abstract) [唐文家, 何德奎 (2015) 青海省外来鱼类调查(2001-2014年). 湖泊科学, 27, 502-510.]

Tian LT, Zhao XY, Wang NG, Li W, Peng Y, Cai X (2016) FTIR spectra and their taxonomic significance of nine Euphorbia species in Shaanxi. Bulletin of Botanical Research, 36, 310-315. (in Chinese with English abstract) [田兰婷, 赵雪艳, 王宁果, 李伟, 彭勇, 蔡霞 (2016) 陕西9 种大戟属植物红外光谱分析及其分类学意义. 植物研究, 36, 310-315.]

Wei JF (2019) Morphological Characteristics Affect Individual Mate Choice Decisions in Female and Male Western Mosquito Fish (Gambusia affinis). Master's dissertation, Northwest A \& F University, Xi'an. (in Chinese with English abstract) [魏洁菲 (2019) 形态特征对雌雄两性西 部食蚊鱼配偶选择决策的影响. 硕士学位论文, 西北农林科技大学, 西安.] 
殷万东, 吴明可, 田宝良，于宏伟，王麒云，丁建清 (2020) 生物入侵对黄河流域生态系统的影响及对策. 生物多样性, 2020, 28 (12): 1533-1545. http://www.biodiversity-science.net/CN/10.17520/biods.2020208

Xu HG, Qiang S (2017) China Invasive Alien Species. Science Press, Beijing. (in Chinese) [徐海根, 强胜 (2017) 中国外来入侵生物. 科学出版社, 北京.]

Yang YF, Yan FF, Zhang RP, Huang Y, Shen XX, Li MY (2020) Progresses in the biology, forecast and management technology of Bemisia tabaci. Anhui Agricultural Science Bulletin, 26, 101-103. (in Chinese with English abstract) [杨益芬, 间芳芳, 张瑞平, 黄岩, 沈祥祥, 李茂业 (2020) 烟粉虫的生物学特性、测报及防控技术研究进展. 安徽农学通报, 26, 101-103.]

Zhou W, Zhao H, Yang X (2012) Prediction of potential geographic distribution areas for Rana catesbiana and Mikania micrantha in China using GARP Modeling System. Journal of Southwest Forestry University, 32(1), 51-55. (in Chinese with English abstract) [周伟, 赵衡, 杨熙 (2012) 利用GARP生态位模型预测牛蛙和薇甘菊在中国的地理分布. 西南林业大学学报, 32(1), 51-55.]

Zhou WJ, Wu YY, Zheng SS, Zheng QQ, Li Q, Ding BY (2011) Allelopathic effect of Acacia mearnsii on the seed germination of several plants. Bulletin of Botanical Research, 31, 235-240. (in Chinese with English abstract) [周伟佳, 吴颖胤, 郑思思, 郑倩倩, 李琼, 丁炳扬 (2011) 黑 荆(Acacia mearnsii)对几种林下植物种子萌发的化感作用. 植物研究, 31, 235-240.]

Zou Q, Xiao M, Jiang X, Hong J, Chen KL, Chen X, Cao YQ (2020) Dynamics of imported red fire ant Solenopsis invicta in Xichang of Sichuan Province. Journal of Xichang University (Natural Science Edition), 34, 54-56. (in Chinese with English abstract) [邹勤, 肖蒙, 蒋金金, 洪杰, 陈 开兰, 陈旭, 曹艳秋 (2020) 四川西昌红火蚁消长规律. 西昌学院学报 (自然科学版), 34, 54-56.] 
殷万东，吴明可，田宝良，于宏伟，王麒云，丁建清 (2020) 生物入侵对黄河流域生态系统的影响及对策. 生物多样性, 2020, 28 (12): 1533-1545. http://www.biodiversity-science.net/CN/10.17520/biods.2020208

附录3 生态环境部公布的重大危害外来物种在黄河九省区的分布情况

Appendix 3 Distribution of the most harmful alien species announced by Ministry of Ecology and Environment in nine provinces of the Yellow River

\begin{tabular}{|c|c|c|c|c|c|c|c|c|c|c|}
\hline \multirow{2}{*}{$\begin{array}{l}\text { 物种 } \\
\text { Species }\end{array}$} & \multicolumn{9}{|c|}{ 分布地点 Distribution area } & \multirow[b]{2}{*}{$\begin{array}{l}\text { 参考文献 } \\
\text { Reference }\end{array}$} \\
\hline & $\begin{array}{l}\text { 青海 } \\
\text { Qing } \\
\text { hai }\end{array}$ & $\begin{array}{l}\text { 四川 } \\
\text { Sichuan }\end{array}$ & $\begin{array}{l}\text { 甘肃 } \\
\text { Gansu }\end{array}$ & $\begin{array}{l}\text { 宁夏 } \\
\text { Ningxi } \\
\text { a }\end{array}$ & $\begin{array}{l}\text { 内蒙古 } \\
\text { Neimong } \\
\text { ol }\end{array}$ & $\begin{array}{l}\text { 山西 } \\
\text { Shanxi }\end{array}$ & $\begin{array}{l}\text { 陕西 } \\
\text { Shaanxi }\end{array}$ & $\begin{array}{l}\text { 河南 } \\
\text { Henan }\end{array}$ & $\begin{array}{l}\text { 山东 } \\
\text { Shan } \\
\text { dong }\end{array}$ & \\
\hline $\begin{array}{l}\text { 紫茎泽兰 } \\
\text { Eupatorium } \\
\text { adenophorum }\end{array}$ & - & $\sqrt{ }$ & - & - & - & - & - & - & - & 赵浩宇等, 2020 \\
\hline $\begin{array}{l}\text { 喜早莲子草 } \\
\text { Alternanthera } \\
\text { philoxeroides }\end{array}$ & - & $\sqrt{ }$ & - & $\sqrt{ }$ & $\sqrt{ }$ & $\sqrt{ }$ & $\sqrt{ }$ & $\sqrt{ }$ & $\sqrt{ }$ & 刘伟, 2012 \\
\hline $\begin{array}{l}\text { 豚草 Ambrosia } \\
\text { artemisiifolia }\end{array}$ & - & $\sqrt{ }$ & - & - & - & - & - & $\sqrt{ }$ & $\sqrt{ }$ & 王晓红, 2019 \\
\hline $\begin{array}{l}\text { 毒麦 Lolium } \\
\text { temulentum }\end{array}$ & $\sqrt{ }$ & $\sqrt{ }$ & $\sqrt{ }$ & $\sqrt{ }$ & $\sqrt{ }$ & $\sqrt{ }$ & $\sqrt{ }$ & $\sqrt{ }$ & $\sqrt{ }$ & $\begin{array}{l}\text { 何剑和渊建民, } \\
2003 \text {; 冯晶, } \\
2016\end{array}$ \\
\hline $\begin{array}{l}\text { 互花米草 } \\
\text { Spartina alterniflora }\end{array}$ & - & - & - & - & - & - & - & - & $\sqrt{ }$ & 栾兆擎等, 2020 \\
\hline $\begin{array}{l}\text { 凤眼莲 } \\
\text { Eichhornia crassipes }\end{array}$ & - & $\sqrt{ }$ & - & - & - & - & - & $\sqrt{ }$ & $\sqrt{ }$ & 秦智雅等, 2016 \\
\hline $\begin{array}{l}\text { 假高粱 } \\
\text { Sorghum halepense }\end{array}$ & - & - & - & - & - & - & - & - & $\sqrt{ }$ & $\begin{array}{l}\text { 雷军成和徐海 } \\
\text { 根, } 2011\end{array}$ \\
\hline $\begin{array}{l}\text { 美国白蛾 } \\
\text { Hyphantria cunea }\end{array}$ & - & - & - & - & - & - & $\sqrt{ }$ & $\sqrt{ }$ & $\sqrt{ }$ & $\begin{array}{l}\text { 李淑贤, 2009; } \\
\text { 潘孟等, } 2020\end{array}$ \\
\hline $\begin{array}{l}\text { 红脂大小蛽 } \\
\text { Dendroctonus valens }\end{array}$ & - & - & - & - & - & $\sqrt{ }$ & $\sqrt{ }$ & $\sqrt{ }$ & - & 姚剑等, 2008 \\
\hline $\begin{array}{l}\text { 蔗扁蛾 Opogona } \\
\text { sacchari }\end{array}$ & - & $\sqrt{ }$ & $\sqrt{ }$ & - & - & $\sqrt{ }$ & - & $\sqrt{ }$ & $\sqrt{ }$ & 沈幼莲, 2008 \\
\hline $\begin{array}{l}\text { 牛蛙 Rana } \\
\text { catesbiana }\end{array}$ & $\sqrt{ }$ & $\sqrt{ }$ & $\sqrt{ }$ & $\sqrt{ }$ & $\sqrt{ }$ & $\sqrt{ }$ & $\sqrt{ }$ & $\sqrt{ }$ & $\sqrt{ }$ & 周伟等, 2012 \\
\hline $\begin{array}{l}\text { 反枝苋 Amaranthus } \\
\text { retroflexus }\end{array}$ & $\sqrt{ }$ & $\sqrt{ }$ & $\sqrt{ }$ & $\sqrt{ }$ & $\sqrt{ }$ & $\sqrt{ }$ & $\sqrt{ }$ & $\sqrt{ }$ & $\sqrt{ }$ & 刘伟, 2006 \\
\hline $\begin{array}{l}\text { 钻叶紫苑 } \\
\text { Aster subulatus }\end{array}$ & $\sqrt{ }$ & $\sqrt{ }$ & - & - & - & - & $\sqrt{ }$ & $\sqrt{ }$ & - & $\begin{array}{l}\text { 徐海根和强胜, } \\
2017\end{array}$ \\
\hline $\begin{array}{l}\text { 鬼针草 } \\
\text { Bidens pilosa }\end{array}$ & $\sqrt{ }$ & $\sqrt{ }$ & $\sqrt{ }$ & $\sqrt{ }$ & $\sqrt{ }$ & $\sqrt{ }$ & $\sqrt{ }$ & $\sqrt{ }$ & $\sqrt{ }$ & $\begin{array}{l}\text { 邓玲姣和邹知 } \\
\text { 明, } 2012\end{array}$ \\
\hline $\begin{array}{l}\text { 小白酒草 } \\
\text { Conyza canadensis }\end{array}$ & - & $\sqrt{ }$ & $\sqrt{ }$ & - & $\sqrt{ }$ & $\sqrt{ }$ & $\sqrt{ }$ & $\sqrt{ }$ & $\sqrt{ }$ & 徐海根等, 2004 \\
\hline $\begin{array}{l}\text { 一年蓬 } \\
\text { Erigeron annuus }\end{array}$ & $\sqrt{ }$ & $\sqrt{ }$ & $\sqrt{ }$ & $\sqrt{ }$ & $\sqrt{ }$ & $\sqrt{ }$ & $\sqrt{ }$ & $\sqrt{ }$ & $\sqrt{ }$ & 王瑞等, 2010 \\
\hline $\begin{array}{l}\text { 尼罗罗非鱼 } \\
\text { Oreochromis niloticus }\end{array}$ & - & - & - & - & - & - & - & - & $\sqrt{ }$ & 王瑶瑶, 2019 \\
\hline $\begin{array}{l}\text { 悬铃木方翅网蝽 } \\
\text { Corythucha ciliate }\end{array}$ & $\sqrt{ }$ & $\sqrt{ }$ & $\sqrt{ }$ & - & - & - & $\sqrt{ }$ & $\sqrt{ }$ & $\sqrt{ }$ & $\begin{array}{l}\text { 鞠瑞亭和李博, } \\
2010\end{array}$ \\
\hline $\begin{array}{l}\text { 扶桑绵粉蚧 } \\
\text { Phenacoccus } \\
\text { solenopsis }\end{array}$ & - & $\sqrt{ }$ & - & - & - & - & - & - & - & 王玉生, 2019 \\
\hline $\begin{array}{l}\text { 垂序商陆 } \\
\text { Phytolacca americana }\end{array}$ & - & $\sqrt{ }$ & - & - & - & $\sqrt{ }$ & $\sqrt{ }$ & $\sqrt{ }$ & $\sqrt{ }$ & $\begin{array}{l}\text { 徐海根和强胜, } \\
2017\end{array}$ \\
\hline
\end{tabular}


殷万东，吴明可，田宝良，于宏伟，王麒云，丁建清 (2020) 生物入侵对黄河流域生态系统的影响及对策. 生物多样性, 2020, 28 (12): 1533-1545. http://www.biodiversity-science.net/CN/10.17520/biods.2020208

附录 3 (续) Appendix 3 (continued)

分布地点 Distribution area

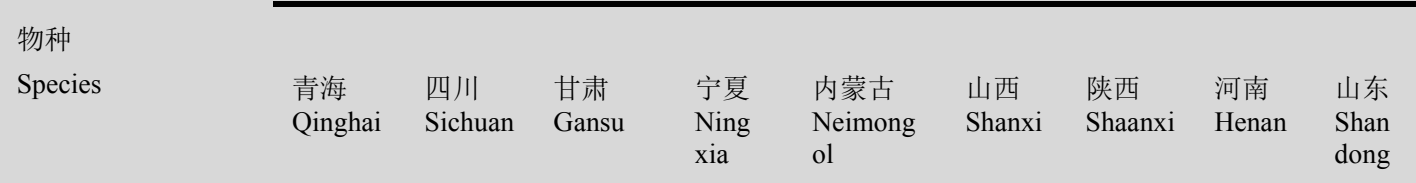

\begin{tabular}{|c|c|c|c|c|c|c|c|c|c|c|}
\hline $\begin{array}{l}\text { 苦颠茄 } \\
\text { Solanum khasianum }\end{array}$ & - & $\sqrt{ }$ & - & - & - & - & - & - & - & 付俊鹏, 2012 \\
\hline $\begin{array}{l}\text { 黄花刺茄 } \\
\text { Solanum rostratum }\end{array}$ & - & - & - & - & $\sqrt{ }$ & $\sqrt{ }$ & - & - & - & 郭晓艳等, 2012 \\
\hline $\begin{array}{l}\text { 蕉香蓟 } \\
\text { Ageratum } \\
\text { conyzoides }\end{array}$ & - & $\sqrt{ }$ & - & - & - & - & - & - & - & 刘碧英等, 2011 \\
\hline $\begin{array}{l}\text { 大狼杷草 } \\
\text { Bidens frondosa }\end{array}$ & $\sqrt{ }$ & $\sqrt{ }$ & $\sqrt{ }$ & $\sqrt{ }$ & $\sqrt{ }$ & $\sqrt{ }$ & $\sqrt{ }$ & $\sqrt{ }$ & $\sqrt{ }$ & $\begin{array}{l}\text { 徐海根和强胜, } \\
2017\end{array}$ \\
\hline $\begin{array}{l}\text { 野燕麦 } \\
\text { Avena fatua }\end{array}$ & $\sqrt{ }$ & $\sqrt{ }$ & $\sqrt{ }$ & $\sqrt{ }$ & $\sqrt{ }$ & $\sqrt{ }$ & $\sqrt{ }$ & $\sqrt{ }$ & $\sqrt{ }$ & $\begin{array}{l}\text { 曹立耘, 2013; } \\
\text { 郑殿升, } 2010\end{array}$ \\
\hline $\begin{array}{l}\text { 食蚊鱼 } \\
\text { Gambusia affinis }\end{array}$ & $\sqrt{ }$ & $\sqrt{ }$ & $\sqrt{ }$ & $\sqrt{ }$ & $\sqrt{ }$ & $\sqrt{ }$ & $\sqrt{ }$ & $\sqrt{ }$ & $\sqrt{ }$ & 魏洁菲, 2019 \\
\hline $\begin{array}{l}\text { 美洲大蠊 } \\
\text { Periplaneta } \\
\text { americana }\end{array}$ & - & $\sqrt{ }$ & - & - & - & - & - & - & $\sqrt{ }$ & $\begin{array}{l}\text { 贺盼和马强, } \\
2018\end{array}$ \\
\hline $\begin{array}{l}\text { 德国小蠊 } \\
\text { Blattella germanica }\end{array}$ & $\sqrt{ }$ & $\sqrt{ }$ & $\sqrt{ }$ & $\sqrt{ }$ & $\sqrt{ }$ & $\sqrt{ }$ & $\sqrt{ }$ & $\sqrt{ }$ & $\sqrt{ }$ & $\begin{array}{l}\text { 贺盼和马强, } \\
2018 ; \text { 霍新北, } \\
2015\end{array}$ \\
\hline $\begin{array}{l}\text { 无花果蜡蚧 } \\
\text { Ceroplastes rusci }\end{array}$ & - & $\sqrt{ }$ & - & - & - & - & - & - & - & $\begin{array}{l}\text { 李海斌和武三 } \\
\text { 安, } 2013\end{array}$ \\
\hline $\begin{array}{l}\text { 松树蜂 } \\
\text { Sirex noctilio }\end{array}$ & - & - & - & - & $\sqrt{ }$ & - & - & - & - & 王明等, 2017 \\
\hline $\begin{array}{l}\text { 三裂叶豚草 } \\
\text { Ambrosia trifida }\end{array}$ & - & $\sqrt{ }$ & - & - & $\sqrt{ }$ & $\sqrt{ }$ & - & - & $\sqrt{ }$ & $\begin{array}{l}\text { 赵浩宇等, 2018; } \\
\text { 魏守辉等, } 2006\end{array}$ \\
\hline $\begin{array}{l}\text { 加拿大一枝黄花 } \\
\text { Solidago canadensis }\end{array}$ & - & $\sqrt{ }$ & - & - & - & - & - & $\sqrt{ }$ & - & 孙晓方, 2020 \\
\hline $\begin{array}{l}\text { 黄顶菊 } \\
\text { Flaveria bidentis }\end{array}$ & - & - & - & - & - & - & - & $\sqrt{ }$ & $\sqrt{ }$ & 祁小旭, 2019 \\
\hline $\begin{array}{l}\text { 土荆芥 } \\
\text { Chenopodium } \\
\text { ambrosioides }\end{array}$ & - & $\sqrt{ }$ & - & - & - & - & $\sqrt{ }$ & - & $\sqrt{ }$ & $\begin{array}{l}\text { 徐海根和强胜, } \\
2017\end{array}$ \\
\hline $\begin{array}{l}\text { 刺苋 } \\
\text { Amaranthus } \\
\text { spinosus }\end{array}$ & - & $\sqrt{ }$ & $\sqrt{ }$ & - & - & $\sqrt{ }$ & $\sqrt{ }$ & - & $\sqrt{ }$ & 王瑞, 2006 \\
\hline $\begin{array}{l}\text { 落葵薯 } \\
\text { Anredera cordifolia }\end{array}$ & - & $\sqrt{ }$ & - & - & - & - & - & - & - & $\begin{array}{l}\text { 徐海根和强胜, } \\
2017\end{array}$ \\
\hline $\begin{array}{l}\text { 稻水象甲 } \\
\text { Lissorhoptrus } \\
\text { oryzophilus }\end{array}$ & - & - & - & - & - & - & - & $\sqrt{ }$ & $\sqrt{ }$ & 黄华等, 2020 \\
\hline $\begin{array}{l}\text { 红火蚁 } \\
\text { Solenopsis invicta }\end{array}$ & - & $\sqrt{ }$ & - & - & - & - & - & - & - & 吴文佳等, 2019 \\
\hline $\begin{array}{l}\text { 克氏原螯虾 } \\
\text { Procambarus clarkii }\end{array}$ & - & $\sqrt{ }$ & $\sqrt{ }$ & $\sqrt{ }$ & - & $\sqrt{ }$ & $\sqrt{ }$ & $\sqrt{ }$ & $\sqrt{ }$ & $\begin{array}{l}\text { 闵云艺, 2017; } \\
\text { 刘训猛等, } 2013\end{array}$ \\
\hline $\begin{array}{l}\text { 苹果蛊蛾 } \\
\text { Cydia pomonella }\end{array}$ & - & - & $\sqrt{ }$ & - & - & - & - & - & - & 吴永美等, 2018 \\
\hline
\end{tabular}


殷万东, 吴明可, 田宝良，于宏伟，王麒云，丁建清 (2020) 生物入侵对黄河流域生态系统的影响及对策. 生物多样性, 2020, 28 (12): 1533-1545. http://www.biodiversity-science.net/CN/10.17520/biods.2020208

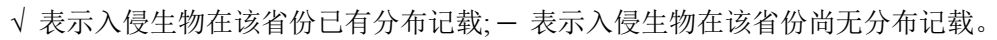

$\sqrt{ }$ indicates that this invasive species has been recorded in this province; - indicates that this invasive species has not been recorded in this province.

\section{参考文献}

Cao LY (2013) Causes and control of weed damage of wild oat in wheat field. Pesticide Market News, 14(29), 41-42. (in Chinese) [曹立耘 (2013) 麦田野燕麦草害上升原因及防除. 农药市场信息, 14(29), 41-42.]

Deng LJ, Zou ZM (2012) Growth regularity, seed propagation and control effect of Bidens pilosa. Southwest China Journal of Agricultural Sciences, 25, 1460-1463. (in Chinese with English abstract) [邓玲姣, 邹知明 (2012) 三叶鬼针草生长、繁殖规律与防除效果研究. 西南农业学报, 25, 1460-1463.]

Feng J (2016) Study on Pest Risk Analysis for the Importation of Alfalfa Hay (Medicago sativa) from Sudan. Master's dissertation, Zhejiang University, Hangzhou. (in Chinese with English abstract) [冯晶 (2016) 进境苏丹苜宿草风险分析与评估研究. 硕士学位论文, 浙江大学, 杭州.]

Fu JP (2012) The Spatial Pattern of Phytolacca americana Linn. and its Control Techniques in Sandy Coastal Shelter Forests. Master's dissertation, Shandong Agricultural University, Taian. (in Chinese with English abstract) [付俊鹏 (2012) 沙质海岸防护林垂序商陆的空间分布格局及其 防控技术研究. 硕士学位论文, 山东农业大学, 泰安.]

Guo XY, Zhang JZ, Guo WD, Lu C (2012) Biological characteristics, hazards and prevention and control of alien invasive plants-Solanum rostratum. Inner Mongolia Forestry Investigation and Design, 35(6), 73-75. (in Chinese with English abstract) [郭晓艳, 张精哲, 郭卫东, 陆超 (2012) 外来入侵植物一一黄花刺茄的生物学特性、危害与防控. 内蒙古林业调查设计, 35(6), 73-75.]

He J, Yuan JM (2003) Comprehensive control measures of poisonous wheat in Chenggu County. Plant Quarantine, 25(2), 124. (in Chinese) [何剑, 波 建民 (2003) 城固县毒麦的综合治理措施. 植物检疫, 25(2), 124.]

He P, Ma Q (2018) Distribution and control of cockroaches in China. Journal of Medical Pest Control, 34, 868-872. (in Chinese with English abstract) [贺盼，马强 (2018) 我国蜚蠊的分布及防制概况. 医学动物防制, 34, 868-872.]

Huang H, Mao HY, Chen C, Peng J, Huang W (2020) Epidemic situation monitoring and comprehensive control countermeasures of rice water weevil in Xinyang. China Agricultural Technology Extension, 36(1), 85-88. (in Chinese) [黄华, 毛红彦, 陈昌, 彭娟, 黄伟 (2020) 信阳地区稻水象 甲疫情监测与综合防控对策. 中国农技推广, 36(1), 85-88.]

Huo XB (2015) Invasion of Blattella germanica and its infestation management in urban environment in China. Chinese Journal of Vector Biology and Control, 26, 114-116. (in Chinese with English abstract) [霍新北 (2015) 我国城市德国小蠊的入侵及预防控制. 中国媒介生物学及控 制杂志, 26, 114-116.]

Ju RT, Li B (2010) Sycamore lace bug, Corythucha ciliata, an invasive alien pest rapidly spreading in urban China. Biodiversity Science, 18, 638646. (in Chinese with English abstract) [鞠瑞亭, 李博 (2010) 悬铃木方翅网蝽: 一种正在迅速扩张的城市外来入侵害虫. 生物多样性, 18, 638-646.]

Lei JC, Xu HG (2011) Prediction of the potential distribution of the alien invasive plant Sorghum halepense in China. Plant Protection, 37(3), 87-92. (in Chinese with English abstract) [雷军成, 徐海根 (2011) 外来入侵植物假高梁在我国的潜在分布区分析. 植物保护, 37(3), 87-92.]

Li HB, Wu SA (2013) Introduction to a new invasive pest, Ceroplastes rusci (Linnaeus) (Hemiptera : Coccoidea : Coccidae). Chinese Journal of Applied Entomology, 50, 1295-1300. (in Chinese with English abstract) [李海斌, 武三安 (2013) 外来入侵新害虫一一无花果蜡蚧. 应用昆 虫学报, 50, 1295-1300.]

Li SX, Gao BJ, Zhang DF, Ning C, Qu JL (2009) Studies of risk assessment of Hypanthia cunea (Drury). Chinese Agricultural Science Bulletin, 25, 202-206. (in Chinese with English abstract) [李淑贤, 高宝嘉, 张东风, 宁超, 屈金亮 (2009) 美国白蛾危险性评估研究. 中国农学通报, 25, 202-206.]

Liu BY, Pan YZ, Zhao YD, Cai L, Hou Y, Yang H, Zhang JF (2011) Effects of Pb stress on nutrient accumulation and allocation of Ageratum conyzoides. Journal of Agro-Environment Science, 30, 435-442. (in Chinese with English abstract) [刘碧英, 潘远智, 赵杨迪, 蔡蕾, 侯艳, 杨慧，张建芳 (2011) Pb 胁迫对蒦香蓟(Ageratum conyzoides)营养积累与分配的影响. 农业环境科学学报, 30, 435-442.]

Liu W (2006) Geographical Range and Possible Distribution Prediction of Several Main Species in Amaranthus in the World. Master's dissertation, Institute of Botany, Chinese Academy of Sciences, Beijing. (in Chinese with English abstract) [刘伟 (2006) 苋属入侵种的可能分布区预测及 相关环境因子分析. 硕士学位论文, 中国科学院植物研究所, 北京.]

Liu W (2012) Research on the Biocontrol Technology, Mechanism and Utilization of Alligator Weed (Alternanthera philoxeroides). Master's 
殷万东, 吴明可, 田宝良, 于宏伟, 王麒云, 丁建清 (2020) 生物入侵对黄河流域生态系统的影响及对策. 生物多样性, 2020, 28 (12): 1533-1545. http://www.biodiversity-science.net/CN/10.17520/biods.2020208

dissertation, East China Normal University, Shanghai. (in Chinese with English abstract) [刘伟 (2012) 喜早莲子草的生物防治技术、机理及 资源化利用研究. 硕士学位论文, 华东师范大学, 上海.]

Liu XM, Zhao YQ, Chen J (2013) Research progress on diseases and control techniques of Procambarus clarkii in China. China Fisheries, 56(10), 64-66. (in Chinese) [刘训猛，赵宜清，陈静 (2013) 我国克氏原螯虾病害及防治技术研究进展. 中国水产, 56(10), 64-66.]

Luan ZQ, Yan DD, Xue YY, Shi D, Xu DD, Liu B, Wang LB, An YT (2020) Research progress on the ecohydrological mechanisms of Spartina alterniflora invasion in coastal wetlands. Journal of Agricultural Resources and Environment, 37, 469-476. (in Chinese with English abstract) [奕兆擎, 间丹丹, 薛媛媛, 史丹, 徐丹丹, 刘彬, 王立波, 安玉亭 (2020) 滨海湿地互花米草入侵的生态水文学机制研究进展. 农业资源 与环境学报, 37, 469-476.]

Min YY (2017) A Preliminary Study on the Comparison of the Efficiency of Crayfish and Crab Culture in Jianghan Area. Master's dissertation, Yangtze University, Jingzhou. (in Chinese with English abstract) [闵云艺 (2017) 江汉地区虾蟹养殖模式效益比较的初步研究. 硕士学位论 文, 长江大学, 荆州.]

Pan M, Sun XJ, Zou B (2020) Rapid control methods of Hyphantria cunea in Nanyang City. Xiandai Horticulture, 43(9), 191. (in Chinese) [潘孟, 孙 新杰, 刍波 (2020) 南阳市美国白蛾快速防控方法. 现代园艺, 43(9), 191.]

Qi XX (2006) Effect of Flaveria bidentis Invasion on Plant Community and Soil Biological Community of Invaded Soil. Master's dissertation, Shenyang Agricultural University, Shenyang. (in Chinese with English abstract) [祁小旭 (2019) 黄顶菊对入侵地植物群落和土壤生物群落特 征的影响. 硕士学位论文, 沈阳农业大学, 沈阳.]

Qin ZY, Tao JY, Hu C, Ruan AD (2016) Distribution, influence and control measures of Eichhornia crassipes in China. Journal of Anhui Agricultural Sciences, 44, 81-84. (in Chinese with English abstract) [秦智雅, 陶景怡, 胡辰, 阮爱东 (2016) 我国水域水葫芦的分布·影响·防治措施. 安 徽农业科学, 44, 81-84.]

Shen YL (2008) Review on the research of Opogona sacchari. Zhejiang Entomological Society: Zhejiang Science and Technology Association, 174179. Hangzhou. (in Chinese) [沈幼莲 (2008) 蔗扁蛾研究综述. 浙江省昆虫学会: 浙江省科学技术协会. 174-179. 杭州.]

Sun XF (2020) An analysis of the invasion mechanism of invasive plant Solidago canadensis. Horticulture \& Seed, 40(1), 20-22. (in Chinese with English abstract) [孙晓方 (2020) 浅析入侵植物加拿大一枝黄花的入侵机理. 园艺与种苗, 40(1), 20-22.]

Wang M, Bao M, Ao TG, Ren LL, Luo YQ (2017) Population distribution patterns and ecological niches of two Sirex species damaging Pinus sylvestris var. mongolica. Chinese Journal of Applied Entomology, 54, 924-932. (in Chinese with English abstract) [王明, 保敏, 敖特根, 任利 利, 骆有庆 (2017) 两种共同危害樟子松的树蜂的种群分布格局及生态位对比. 应用昆虫学报, 54, 924-932.]

Wang R (2006) Historical Reconstruction of Invasion and Expansion and Potential Spread of Some Threatening Invasive Alien Species in China. Master’s dissertation, Institute of Botany, Chinese Academy of Sciences, Beijing. (in Chinese with English abstract) [王瑞 (2006) 我国严重威 胁性外来入侵植物入侵与扩散历史过程重建及其潜在分布区的预测. 硕士学位论文, 中国科学院, 北京.]

Wang R, Wang YZ, Wan FH (2010) Spatiotemporal expansion pattern and potential spread of invasive alien plant Erigeron annuus (Asteraceae) in China. Chinese Journal of Ecology, 29, 1068-1074. (in Chinese with English abstract) [王瑞, 王印政, 万方浩 (2010) 外来入侵植物一年蓬 在中国的时空扩散动态及其潜在分布区预测. 生态学杂志, 29, 1068-1074.]

Wang XH (2019) Harm and control of Ambrosia artemisiifolia to grassland. Animal Husbandry in Xinjiang, 34(4), 44-46. (in Chinese) [王晓红 (2019) 杂草豚草对草原的危害及防控. 新疆畜牧业, 34(4), 44-46.]

Wang YS (2019) Distribution Pattern and Genetic Structure of Pheracoccns Sotenopsis Tinsley and Distribution Pattern of Its Parasitoid Wasps in China. PhD dissertation, Chinese Academy of Agricultural Sciences, Beijing. (in Chinese with English abstract) [王玉生 (2019) 扶桑绵粉蚧在 中国的地理分布与遗传结构及其寄生蜂的地理分布格局研究. 博士学位论文, 中国农业科学院, 北京.]

Wang YY (2019) Gonad Development Examination and Temporal and Spatial Expression Pattern Analysis of Sex Differentiation Related Genes in High Temperature Treated Female Nile Tilapia. Master's dissertation, Shandong Agricultural University, Taian. (in Chinese with English abstract) [王瑶瑶 (2019) 高温处理的尼罗罗非鱼性腺分化过程及性别决定相关基因时空表达模式研究. 硕士学位论文, 山东农业大学, 泰安.]

Wei JF (2019) Morphological Characteristics Affect Individual Mate Choice Decisions in Female and Male Western Mosquito Fish (Gambusia affinis). Master's dissertation, Northwest A \& F University, Xi'an. (in Chinese with English abstract) [魏洁菲 (2019) 形态特征对雌雄两性西 部食蚊鱼配偶选择决策的影响. 硕士学位论文, 西北农林科技大学, 西安.]

Wei SH, Qu Z, Zhang CX, Li YJ, Li XJ (2006) Invasive alien species giant ragweed (Ambrosia trifida L.) and its risk assessment. Plant Protection, 44(4), 14-19. (in Chinese with English abstract) [魏守辉, 曲哲, 张朝贤, 李咏军, 李香菊 (2006) 外来入侵物种三裂叶豚草(Ambrosia trifida L.)及其风险分析. 植物保护, 44(4), 14-19.] 
殷万东, 吴明可, 田宝良，于宏伟，王麒云，丁建清 (2020) 生物入侵对黄河流域生态系统的影响及对策. 生物多样性, 2020,

28 (12): 1533-1545. http://www.biodiversity-science.net/CN/10.17520/biods.2020208

Wu WJ, Wu J, Huang YY (2019) Risk analysis of Solenopsis invicta in Panxi area of Sichuan Province. Applicable Technologies for Rural Areas, 22(11), 50-52. (in Chinese) [吴文佳, 吴款, 黄跃跃 (2019) 四川省攀西地区全国植物检疫性有害生物红火蚁风险性分析. 农村实用技术, 22(11), 50-52.]

Wu YM, Jin B, Gu ZR (2018) The distribution and control of Cydia pomonella (L.). Studies on Insects in Central China, 14, 150-157. (in Chinese with English abstract) [吴永美, 金彪, 谷志容 (2018) 苹果蛽蛾的分布及防控. 华中昆虫研究, 14, 150-157.]

Xu HG, Qiang S (2017) China Invasive Alien Species (revised edition). Science Press, Beijing. (in Chinese) [徐海根, 强胜 (2017) 中国外来入侵 生物. 科学出版社, 北京.]

Yao J, Zhang LW, Yu XF (2008) Advances in red turpentine bark beetle, Dendroctonus valens LeConte. Journal of Anhui Agricultural University, 52, 416-420. (in Chinese with English abstract) [姚剑, 张龙娃, 余晓峰 (2008) 入侵害虫红脂大小蛽的研究进展. 安徽农业大学学报, 52, 416-420.]

Zhao HY, Chen XJ, Liu JD, Liu SN, Zhu JY, Zhou XG (2020) Suggestions on prevention and control of several major invasive pests in Sichuan Province. Sichuan Agriculture and Agricultural Machinery, 27(2), 51-52. (in Chinese) [赵浩宇, 陈晓娟, 刘俊豆, 刘胜男, 朱建义, 周小刚 (2020) 四川几种主要入侵有害生物防治建议. 四川农业与农机, 27(2), 51-52.]

Zheng DS (2010) Diversity of oat in China. Journal of Plant Genetic Resources, 11, 249-252. (in Chinese with English abstract) [郑殿升 (2010) 中 国燕麦的多样性. 植物遗传资源学报, 11, 249-252.]

Zhou W, Zhao H, Yang X (2012) Prediction of potential geographic distribution areas for Rana catesbiana and Mikania micrantha in China using GARP Modeling System. Journal of Southwest Forestry University, 32(1), 51-55. (in Chinese with English abstract) [周伟, 赵衡, 杨熙 (2012) 利用 GARP 生态位模型预测牛蛙和薇甘菊在中国的地理分布. 西南林业大学学报, 32(1), 51-55.] 
殷万东，吴明可，田宝良，于宏伟，王麒云，丁建清 (2020) 生物入侵对黄河流域生态系统的影响及对策. 生物多样性, 2020, 28 (12): 1533-1545. http://www.biodiversity-science.net/CN/10.17520/biods.2020208

\section{附录4 凤眼莲在池塘暴发危害场景}

Appendix 4 The outbreak of water hyacinth (Eichhornia crassipes) in ponds

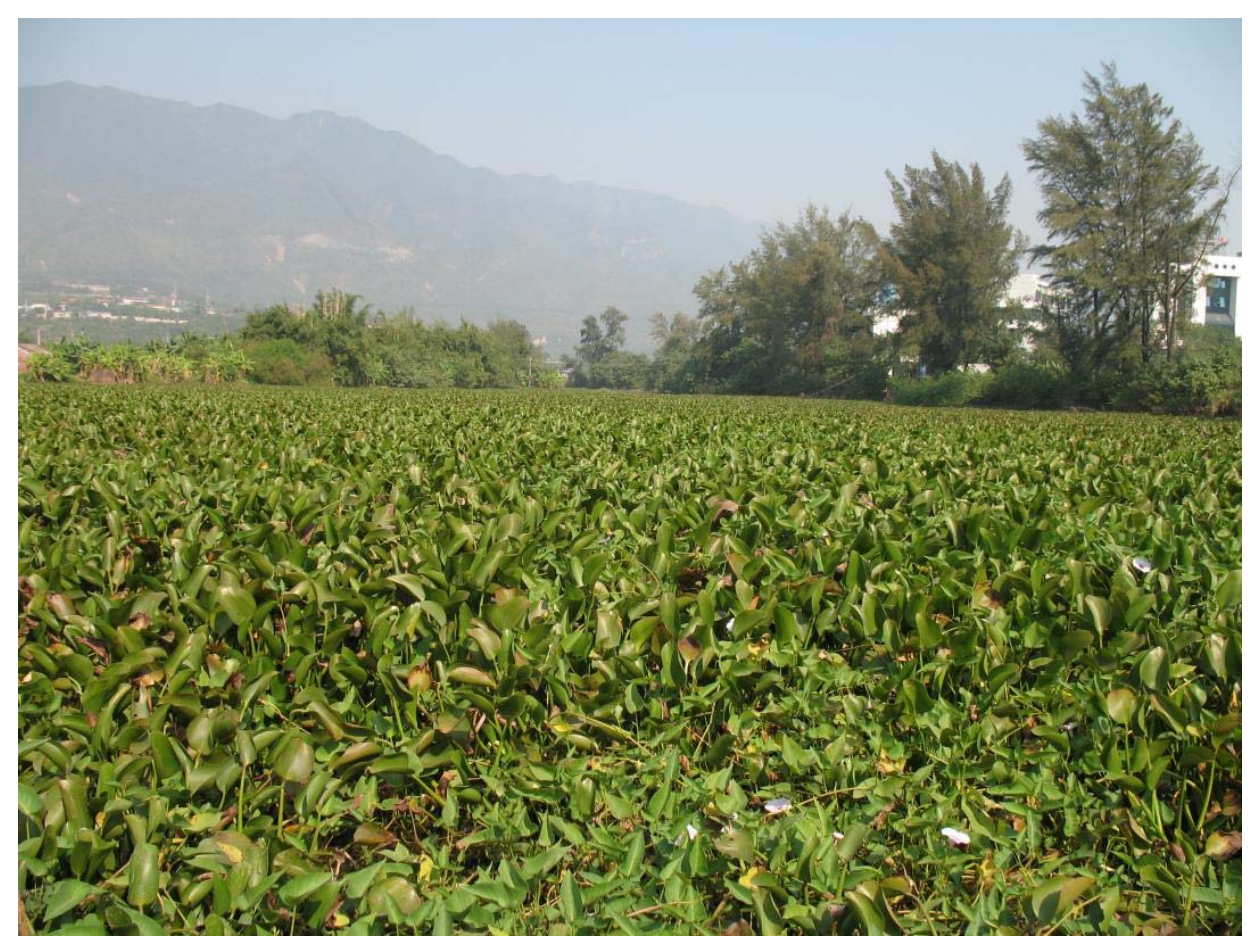


殷万东，吴明可，田宝良，于宏伟，王麒云，丁建清 (2020) 生物入侵对黄河流域生态系统的影响及对策. 生物多样性, 2020, 28 (12): 1533-1545. http://www.biodiversity-science.net/CN/10.17520/biods.2020208

\section{附录5 居民区附近处于开花期的豚草}

Appendix 5 Ambrosia artemisiifolia in flowering stage near residential area

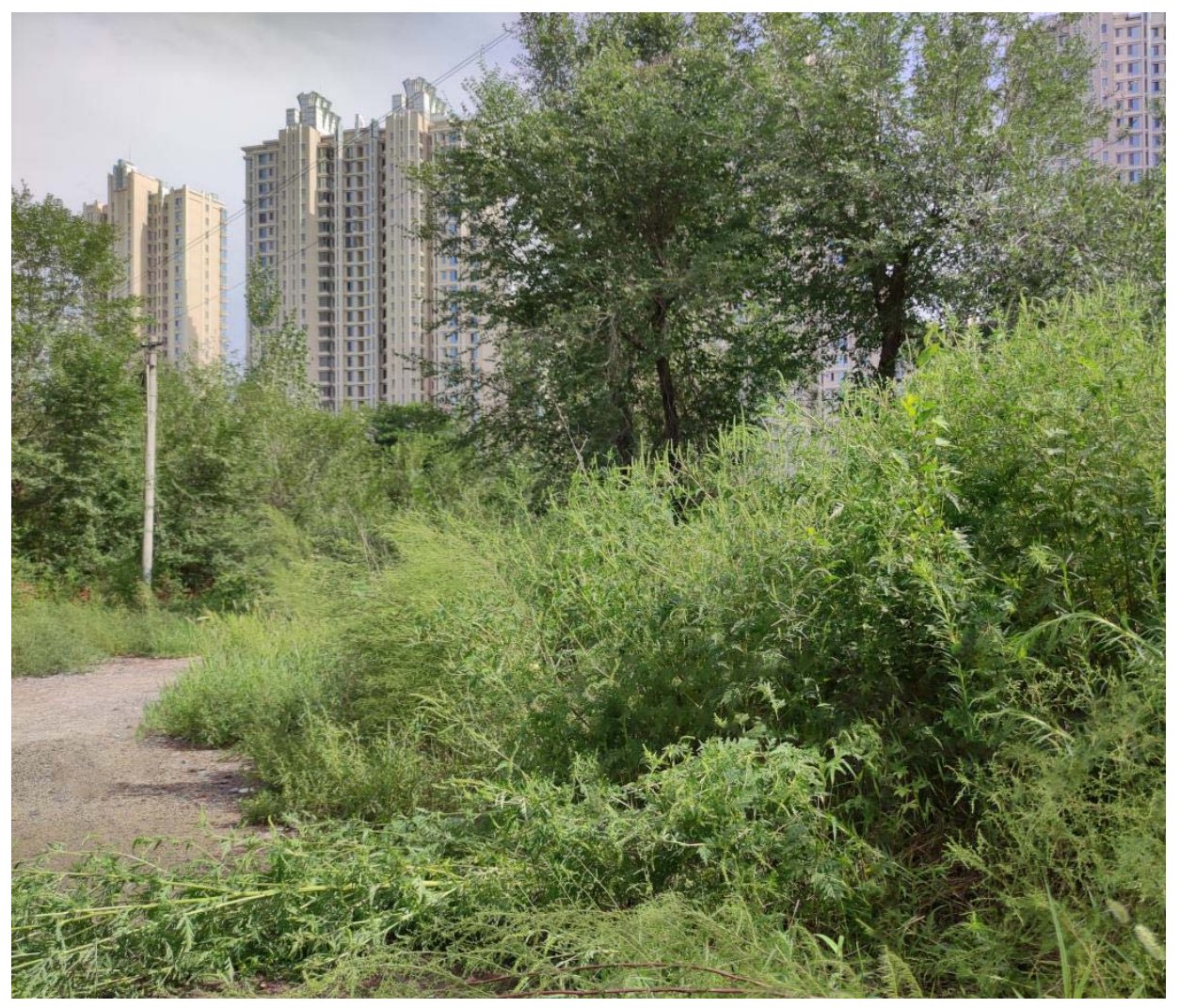

